\title{
LOS ANDES DE BRONCE. CONSCRIPCIÓN MILITAR DE COMUNEROS ANDINOS Y EL SURGIMIENTO DE LAS BANDAS DE BRONCE EN EL NORTE DE CHILE
}

\begin{abstract}
RESUMEN
El artículo analiza el sistema de conscripción militar de ciudadanos desplegada por el Estado chileno. Se discute el tejido temporal de la Ley de reclutamiento del año 1900 , caracterizando el reclutamiento en el territorio nacional, así como en el norte chileno. Se estudia el alistamiento de poblaciones andinas en Chile, dispositivo que permitió a los indígenas incorporarse al Ejército, asumiendo oficios como músicos de batallón, generando a nivel local nuevas prácticas culturales, como aconteció con el surgimiento de las bandas de bronce para acompañar las festividades en poblados y santuarios de los Andes chilenos.
\end{abstract}

Palabras clave: poblaciones andinas, conscripción militar, bandas de bronce.

\begin{abstract}
This article analyzes the system of military conscription displayed by the Chilean State among its citizens. This is studied within the context of the Conscription Law of 1900, providing a characterization of conscription in Chile but especially in its Northern territories. The article explores the conscription in Northern Andean regions, which made possible the military enrolment of indigenous communities in the Chilean Army. Many of these people assumed roles such as Battalion Musicians, making possible the appearance of new cultural practices at a local level. The best example of this, is the emergence of brass bands which became an integral part of festivities in towns and sanctuaries in the Chilean Andes.
\end{abstract}

Key words: Andean communities, Military conscription, Brass Bands.

Fecha de recepción: agosto de 2008

Fecha de aceptación: julio de 2009

\section{INTRODUCCIÓN}

El sistema de conscripción militar, bajo la impronta moderna del EstadoNación, ha sido conceptualizado como un dispositivo que fue utilizado como

\footnotetext{
* Historiador, Magíster en Antropología Social y Doctor en Antropología. Universidad de Tarapacá, Departamento de Ciencias Históricas y Geográficas. Correo electrónico: albertodiaz@uta.cl
} 
mecanismo para la propagación del sentimiento nacional en la población y la reproducción de los vínculos con la Nación ${ }^{1}$. Al mismo tiempo, permite unificar, mediante el uso de la fuerza o el disciplinamiento, el imaginario colectivo de la membresía nacional, imponiendo lenguajes y símbolos que refuerzan la cohesión de la sociedad, asegurando la lealtad de los ciudadanos que comparten tradiciones, costumbres y normativas desplegadas desde el Estado.

Siguiendo estas consideraciones teóricas, es posible argumentar que la conscripción militar, desde su implementación en el año 1900, fue un mecanismo para comprometer a diferentes segmentos de la sociedad chilena con los principios y los valores patrios. Si es así, entonces también es oportuno sostener que el reclutamiento (al igual que la escuela pública) fue un aparato que reprodujo la nación en los territorios anexados tras la Guerra del Pacífico (1883), como fueron Iquique y Arica, hoy el área septentrional del país ${ }^{2}$.

En un escenario territorial donde se proyectan y fraguan los formatos sociopolíticos de la nación, como el que constituye el nuevo norte chileno, es factible problematizar el cómo se hace operativo este dispositivo al interior de la sociedad regional y qué elementos locales surgen como respuesta o adaptación al equipado sistema castrense. Una aproximación válida a esta pregunta pasa por sostener que fue una disposición para chilenizar a una población con un pasado identitario peruano, asegurando -a veces violentamente- la soberanía nacional y la lealtad ciudadana en el territorio, y, a la vez, evitar conflictos e insurrecciones sociales ${ }^{3}$.

Dicho sea de paso, también es posible advertir lo que sucedió con los segmentos indígenas andinos que vivían en los poblados cordilleranos o se movilizaban con sus productos por las quebradas o la pampa del norte de Chile. ¿Participaron aquellos comuneros indígenas del proceso de reclutamiento militar? ¿Qué lecturas se generaron desde las comunidades frente al enrolamiento de comuneros en los regimientos? ¿Qué acciones comunitarias elaboraron?

Una de las temáticas sobre la participación de indígenas en las estructuras nacionales, como es el reclutamiento, ha llamado la atención sobre si los campesinos podrían comprometerse con el Estado moderno o solo han sido meros espectadores de los procesos de cambio social que se han experimentado en los últimos siglos en el área andina.

Existen evidencias de la incorporación de población de raíz indígena en el Ejército peruano durante la Guerra del Pacífico, disputando con fervor varias batallas en las llanuras y serranías del Perú, además de generar reclamos y exigencias sociopolíticas por la tenencia de la tierra, recursos hídricos y acceso a cargos

1 Véase Yves Déloye, Sociología histórica de lo político, Santiago, Lom Ediciones, 2004; Benedict Anderson, Comunidades imaginadas. Reflexiones sobre el origen y difusión del nacionalismo, México D.F., Fondo de Cultura Económica, 1993; Michel Foucault, Vigilar y castigar, México D.F., Siglo XXI Editores, 1997; Pierre Bourdieu y Jean-Claude Passeron, La Reproducción. Elementos para una teoría del sistema de enseñanza, Madrid, Editorial Popular, 2001.

2 Sergio González Miranda, Chilenizando a Tunupa. La escuela pública en el Tarapacá Andino 1880-1990, Santiago, Dirección de Bibliotecas, Archivos y Museos, Centro Barros Arana, 2002.

3 Véase Raúl Palacios, La chilenización de Tacna y Arica 1883-1929, Lima, Editorial Arica, 1974; y Sergio González Miranda, El dios cautivo. Las ligas patrióticas en la chilenización de Tarapacá (1910-1922), Santiago, Lom Ediciones, 2004. 
públicos, como parte del proyecto liberal del siglo XIX ${ }^{4}$. Los comuneros andinos, antes de la llegada del Estado chileno, asumieron diversos compromisos ciudadanos, como una praxis política que se construía no solo en las ciudades, sino también en la periferia de las aldeas serranas.

Bajo estos preceptos, el artículo analiza la incorporación de los comuneros andinos al sistema de conscripción administrado por Chile, a partir de la reforma castrense influenciada por la doctrina militar prusiana. Se exponen antecedentes que describen la normativa de reclutamiento, así como la inserción en los cuarteles de los ciudadanos (incluidos los campesinos), además de las alternativas que la institución castrense ofreció a los soldados.

Una de estas alternativas fue la contratación de músicos de batallones para acompañar a la tropa, interpretando marchas alemanas en instrumentos de bronce (trompetas, tubas, trombones). Conjeturamos que los comuneros, al incorporarse a las "bandas instrumentales del Ejército", aprendieron a musicalizar con nuevos instrumentos de metal las melodías tradicionales andinas e introducir a las prácticas rituales y festivas las "bandas de bronce". Desarrollamos, asimismo, la idea de que estas agrupaciones musicales fueron una respuesta cultural que dinámicamente incorporaron los indígenas en los países andinos, estudiando los matices regionales sobre el surgimiento y significación de las bandas, en un período que arranca con la promulgación de la Ley de reclutamiento, en 1900, y llega hasta mediados del siglo XX, cuando se consolidan las bandas de bronce como manifestación cultural y musical en toda el área andina.

Este estudio aborda un tema que tradicionalmente ha estado circunscrito al ámbito del folclore. Pese a ello, nuestra apuesta intenta comprender las profundidades históricas que contienen las costumbres, como manifestaciones de historicidad de cada sociedad, siguiendo los circuitos simbólicos y sociales que ofrecen al historiador los procesos culturales de las poblaciones indígenas ${ }^{5}$.

4 Al respecto, véanse los trabajos de Nelson Manrique, Yawar Mayu. Sociedades terratenientes serranas. 1879-1910, Lima, Instituto Francés de Estudios Andinos, 1988; y "La historiografía peruana sobre el siglo XIX", en Andina 17, Cusco, 1991; Mark Thurner, "Los indios y la repúblicas entre 18301880", en Juan Maiguashca (ed.), Historia de América Andina, creación de las repúblicas y formación de la nación, vol. 5, Quito, Universidad Andina Simón Bolívar, 2003; Carlos Contreras y Marcos Cueto, Historia del Perú contemporáneo, Lima, Instituto de Estudios Peruanos, 2000; Florencia Mallon, "Entre la utopía y la marginalidad: comunidades indígenas y culturas políticas en México y los Andes 1780-1990", en Historia Mexicana XLII: 2, México D.F., 1989, 473-504; Gabriella Chiaramonti, "A propósito del debate Herrera-Gálvez de 1849: breves reflexiones sobre el sufragio de los indios analfabetos", en Cristóbal Aljovín de Losada y Sinesio López (eds.), Historia de las elecciones en el Perú, Lima, Instituto de Estudios Peruanos, 2005; y Cristóbal Aljovín de Losada, "Prácticas políticas y formación de ciudadanía", en Eduardo Cavieres Figueroa y Cristóbal Aljovín de Losada (comps.), Chile-Perú, Perú-Chile: 1820-1920. Desarrollos políticos, económicos y culturales, Valparaíso, Ediciones Universitarias de Valparaíso, 2005, entre otros. Para el caso mapuche, se ha constreñido la participación a la política restrictiva del Estado, en tal sentido véase Yanko González Cangas, "Servicio militar obligatorio y disciplinamiento cultural: Aproximaciones al caso mapuche-huilliche en el siglo XX", en Alpha 24, Osorno, 2007, 111-137.

5 La investigación reunió información documental de archivos, bibliografía de la época y testimonios de comuneros andinos durante nuestro trabajo de campo. Seguimos, desde una perspectiva histórica, algunas de las orientaciones de Edward P. Thompson, "Folklore, antropología e historia social", en Entrepasados 2, Buenos Aires, 1992; Peter Burke, ¿Qué es la historia cultural?, Barcelona, Paidós, 2006; Mijail Bajtin, La cultura popular en la edad media: el contexto de François Rabelais, Madrid, Alianza, 1981; Eric Hobsbawm y Terence Ranger, La invención de la tradición, Barcelona, Crítica, 2002. 


\section{LA LEY DE RECLUTAMIENTO MILITAR}

La conscripción militar fue uno de los desafíos que asumieron los instructores alemanes contratados por el Estado chileno para reorganizar al Ejército, quienes, a partir de 1887, iniciaron la reforma de la institución encabezada por el capitán prusiano Emilio Körner ${ }^{6}$. En efecto, tras la Guerra del Pacífico, el Ejército se involucró en un proceso de cambios estructurales a nivel orgánico, formativo y logístico, que lo llevó a adoptar -al igual que el Ejército boliviano- el modelo castrense prusiano, lo que significó una profunda reingeniería interna, que lo distanció de la antigua influencia francesa a la cual se adscribía ${ }^{7}$.

Durante gran parte del siglo XIX, el sistema de alistamiento fue voluntario, siendo la Guardia Nacional el estamento comisionado para la instrucción de los reclutas y sirviendo de base en ciertos períodos como parte del contingente nacional que enfrentó las guerras de la Confederación (1836-1839) y del Pacífico $(1879-1883)^{8}$. Esta entidad siguió siendo operativa hasta después de la Revolución de 1891, como parte de la reserva del Ejército9 ${ }^{9}$.

Cuando Körner asumió como general ${ }^{10}$, determinó que el funcionamiento de la Guardia Nacional no se adecuaba a las nuevas exigencias de conscripción, ya que su conformación y el escaso número de voluntarios generaban inseguridad social e inestabilidad geopolítica y diezmaban la modernización institucional ${ }^{11}$. Por tales motivos, el 15 de febrero de 1896, Jorge Montt, siguiendo los requerimientos de Körner, promulga la Ley $\mathrm{N}^{\circ} 352$, llamando a cumplir con la instrucción militar obligatoria a todos los ciudadanos mayores de veinte años, en las zonas militares II y III (centro y centro sur del país).

Para el 5 de septiembre de 1900 fue aprobada la Ley sobre reclutas y reemplazos del Ejército y Armada $\left(\mathrm{N}^{\circ} 1.462\right)^{12}$, cuyas disposiciones generales requerían que:

6 Enrique Brahm García, Preparados para la guerra. Pensamiento militar chileno bajo la influencia alemana. 1885-1930, Santiago, Ediciones Universidad Católica de Chile, 2003, 21.

7 Carlos Maldonado y Patricio Quiroga, "El desarrollo histórico del Ejército chileno", en idem, El prusianismo en las Fuerzas Armadas chilenas. Un estudio histórico, 1885-1945, Santiago, Ediciones Documentas, 1988.

8 Patricio Quiroga, "El predominio de las oligarquías y la prusianización de los ejércitos de Chile y Bolivia (1880-1930)", en Estudios Historiográficos I:1, Valparaíso, 2001, 131.

9 Estado Mayor del Ejército, Historia del Ejército chileno, tomo VII, Santiago, s.e., 1985, 254.

10 Entre 1892 y 1904 Körner ocupó el cargo de jefe del Estado Mayor del Ejército y posteriormente, entre 1904 a 1910, el de inspector general del Ejército de Chile, desplegando la ideología alemana en todas las actividades militares, doctrina que hacia la década de 1930 perdió influencia en el país; Brahm, op. cit., 25.

11 Estado Mayor, op. cit., 255.

12 Existe una discordancia en la definición numérica de la ley. El Diario Oficial de 1900 y el texto Ordenanza Jeneral del Ejercito (1901) la registran como la Ley $\mathrm{N}^{\circ}$ 1.462; pero en el texto Recopilación de leyes, D.L., D.F.L., reglamentos y decretos del Ejército (1980), aparece con el número 1362. En ambos casos la fecha de aprobación fue el 5 de septiembre de 1900. Aunque existe esta divergencia numérica, los tópicos reglamentarios son los mismos. Cfr. Diario Oficial de la República de Chile, Santiago, 5 de septiembre de 1900; Ordenanza Jeneral del Ejercito, Santiago, Imprenta Nacional, 1901; Recopilación de leyes, D.L., D.F.L., reglamentos y decretos del Ejército, Santiago, Ejército de Chile, 1980. 
“Art. $1^{\circ}$ Todos los chilenos de veinte a cuarenta i cinco años de edad, en estado de cargar armas, están obligados a servir en el ejército de la República en la forma establecida en esta lei.

Art. $2^{\circ}$ Estos servicios se prestarán:

$1^{\circ}$ Por un año en el Ejército activo, desde los veinte a los veintiun años de edad, debiendo servir en Cuerpo, nueve meses a lo menos;

$2^{\circ}$ En la primera reserva durante nueve años contados desde el licenciamiento en el Ejército activo; i

$3^{\circ}$ En la segunda reserva desde el licenciamiento en la primera reserva hasta los cuarenta i cinco años de edad.

Los ciudadanos que no fueren llamados a servir en el Ejército activo por no estar comprendidos en el continjente anual en el caso a que se refiere el artículo 17, pasarán a las reservas conjuntamente con los que hayan hecho sus servicios.

El tiempo a que se refiere este artículo se contará desde el $1^{\circ}$ de enero del año en que se cumple la edad respectiva"13.

La ley describe la envergadura con que se pretendió congregar a un número importante de hombres para realizar el servicio militar, amén de las disposiciones y esfuerzos desplegados por la comandancia, para materializar la nueva estructura militar y hacer de Chile "una nación en armas"14. Estos instructivos fueron aplicados en todo el territorio chileno, incluyendo la zona de Tacna y Arica, que permanecía bajo un litigio diplomático ${ }^{15}$.

\section{RECLUTAMIENTO MILITAR EN EL NORTE CHILENO}

De acuerdo a la Ley sobre reclutas y reemplazos, la inscripción militar debía realizarse, a nivel provincial, en juntas vinculadas a las circunscripciones del Re-

13 Diario Oficial de la República de Chile, Santiago, 5 de Septiembre de 1900.

14 Körner, expresa que "una nación en armas" se refleja en "el conscripto que debía reemplazar al mercenario. La enseñanza militar debía ser tan obligatoria para los jóvenes como la enseñanza primaria. Al igualar a todos los chilenos, el servicio militar fomentaría el sentimiento nacional enseñando a sacrificar los intereses individuales a favor de los del país y afirmando por lo mismo las ideas republicanas". Brahm, op. cit., 43. Cfr. Emilio Körner, "Proyecto de reclutamiento para el ejército presentado por el Estado Mayor General del Ejército", en Revista Militar 53, Santiago, 1892.

15 Tras la firma del Tratado de Ancón (1883), el área que ocupan Arica y Tacna generó un conflicto diplomático por la soberanía del antiguo sur peruano. El Tratado disponía que, después de la guerra, tanto Tacna como Arica estarían bajo la presencia chilena por diez años; acabado este período, se debía realizar un plebiscito entre la población local para determinar a qué país correspondería la soberanía de las provincias. Sin embargo, después de una serie de entuertos burocráticos, discusiones de cancillerías, variadas interpretaciones geopolíticas y una compleja tensión social, el referéndum plebiscitario no pudo efectuarse. Para 1929, el Tratado de Lima dispuso que Tacna quedaría bajo territorio peruano y Arica pertenecería a Chile, finalizando definitivamente el conflicto. Una descripción detallada en Conrado Ríos, Chile y Perú. Los pactos de 1929, Santiago, Nascimento, 1959; Ernesto Yepes, Un plebiscito imposible... Tacna-Arica 1925-1926, Lima, Ediciones Análisis, 1999; Luis Galdames et al., Historia de Arica, Santiago, Editorial Universitaria, 1981; Alberto Ulloa, Para la historia internacional y diplomática del Perú, Lima, Editorial Atlántida, 1987; Félix Calderón, La otra Historia. El Tratado de 1929, Lima, Fondo Editorial del Congreso del Perú, 2000; y Sergio González Miranda, La llave y el candado. El conflicto entre Perú y Chile por Tacna y Arica, Santiago, Lom Ediciones, 2008. 
gistro Civil (art. 10). Para el caso del extremo norte del país, las juntas de inscripción se localizaron en Tacna, Arica, Iquique y Pisagua, y estuvieron compuestas por el oficial del Registro Civil y dos miembros del Ejército a quienes designaba el jefe de zona (art. 11) ${ }^{16}$. Generalmente, el llamado a inscribirse se realizaba a comienzos de cada año, publicando avisos en la prensa local, además de informar con carteles en plazas o mercados. Asimismo, se divulgaban públicamente las penas a quienes evadían el llamado, siendo multados o incluso llevados a prisión cuando la falta era extrema (art. 36) ${ }^{17}$.

La publicación de los avisos generó en ocasiones un dilema para las autoridades, debido al analfabetismo de la población, equivalente a un 53,2\%, lo que significaba que los periódicos y letreros no eran leídos ${ }^{18}$. Ante tal panorama, literalmente había que salir a "buscar" a los futuros conscriptos por el puerto, la pampa, los valles y serranías ${ }^{19}$.

Circunscribiéndonos a nuestra problemática, para inscribir a los comuneros andinos - considerados como ciudadanos, no por su condición étnica ${ }^{20}-$, se organizaron comisiones especiales que se internaban en la cordillera por semanas, con el objetivo de registrar a todo varón en edad de reclutamiento. En el pueblo de Putre, se recomendó al subdelegado que, ayudado por el

“personal de Policía reclutará jente para enviarla a esta ciudad, a la Comisaría de Policía, debidamente custodiada. Este envío deberá hacerse si es posible, de una sola ves para evitar la deserción de los demás pobladores á quienes también les corresponda hacer su servicio pues el objeto de esta conscripción no es solo recoger

16 Las zonas militares fueron creadas en 1895. Hasta el año 1903, la capital de la zona estuvo en la ciudad de Tacna, donde albergaba, entre otros, a los regimientos Carampangue y Rancagua. En 1903 el mando fue trasladado a Iquique, al igual que el regimiento Carampangue. En 1906 el Ejército se reestructura en Divisiones, Tacna, en ese año, contaba con el regimiento de infantería Rancagua y la compañía de zapadores pontoneros Atacama. Iquique tenía al regimiento de infantería Carampangue y el regimiento de caballería Jeneral Bulnes, después conocido como Granaderos. Arica estaba circunscrita a la administración de Tacna. Francisco Javier Ovalle, La ciudad de Iquique, Iquique, Imprenta Mercantil, 1908, 244

17 El Ferrocarril, Arica, 5 de enero de 1915.

18 Alberto Díaz Araya, "Orden, patria y delincuencia en el desierto chileno. Un estudio cuantitativo sobre la Intendencia de Tacna (1883-1926)", Revista de Historia de América 134, México D.F., 2004, 53-88. En los albores del siglo XX, en pueblos altiplánicos como Guallatire, Parinacota y Caquena, el 95\% de la población era analfabeta, mientras que en Putre, Socoroma, Belén, Chapiquiña, Ticnamar, Livilcar, Humagata, Pachica y Esquiña, la cifra llegaba al 85,2\%, según constatan Julio Aguilar et al., Valle de Codpa: Itinerarios, historias y memorias. s. XIX-XX, Arica, Centro de Escritoras de Arica, 2007.

19 Archivo de la Intendencia de Tarapacá (en adelante AIT), Ejército y Armada, 1907, No 9.

20 Consignemos que, durante la República Peruana (1821-1883), los indígenas andinos tempranamente asumieron condiciones sociopolíticas de ciudadanía y participación cívica. Con la ocupación chilena de los sectores cordilleranos que habían pertenecido al Perú, comenzaron las presiones para asimilar a los comuneros peruanos a los patrones sociales y culturales chilenos, incorporando a los campesinos andinos a las prácticas ciudadanas nacionales, en un territorio políticamente sensible; al respecto, véase Hans Gundermann Kroll, "Comunidad aymara, identidades colectivas y Estados nacionales en los albores del siglo XX", en Pablo Artaza Barrios et al., A 90 años de los sucesos de la Escuela Santa María de Iquique, Santiago, Lom Ediciones, 1998; Alberto Díaz Araya, "Aymaras, peruanos y chilenos en los Andes ariqueños: Resistencia y conflicto frente a la chilenización del norte de Chile", en AIBR 1:2, Madrid, 2006, 275-289. 
ciudadanos que les corresponde hacer su servicio en este año, sino también a los infractores a la ley" 21 .

Del mismo modo, en los valles tarapaqueños se informó a

"carabineros a fin de evitar el éxodo de reclutas, tanto de reservistas, como de ciudadanos estranjeros de los paises limitrofes.- Especialmente me permito insinuar a Us. Una vigilancia especial de los caminos que conducen de Pica al interior, como así mismo enviar comisiones a los centros o lugares que us. estime necesarios"22.

Para sortear problemas, se instruyó a los jueces e inspectores de los distritos rurales sobre las normativas de la convocatoria ${ }^{23}$, requiriendo las nóminas de los campesinos según partidas de nacimiento para corroborar nacionalidades ${ }^{24}$, además de identificar los domicilios que permitieran "instruir sumario contra los remisos" 25 y evitar que eludieran "las obligaciones que les impone la ley"26. También hubo casos donde fue prácticamente imposible localizar a comuneros infractores, ya que residían en caseríos, lugarejos o majadas distantes ${ }^{27}$.

No hemos hallado resistencia violenta a la ley; de hecho, solo se aplicaron sentencias que básicamente consistían en veinte días de prisión y un año de servicio militar (arts. 36 y 37). Existieron situaciones de indígenas buscados como infractores, pero muchos de estos habían cumplido con el proceso de reclutamiento $^{28}$. Hay registros sobre errores en las nóminas de alistamiento por similitudes de nombres o apellidos de raíz indígena entre los campesinos ${ }^{29}$, inquietando a los comisionados militares ${ }^{30}$. Sin duda que los caminos en estado "lastimoso"31, la trashumancia de los ganaderos altiplánicos y la lejanía de las aldeas fueron obstáculos que periódicamente debieron eludir las autoridades, manifestando que era "materialmente imposible fijar en las nóminas el domicilio de muchos por no haber sido encontrado" 32 .

Pese a los inconvenientes, el proceso de conscripción fue instituyéndose como parte de los deberes cívicos que los comuneros andinos asumieron, lo que paulatinamente se materializó en una demanda por la instrucción militar y la participación en ritos colectivos, como desfiles dominicales, retretas patrióticas y conmemoraciones a los héroes ${ }^{33}$, dispositivos sociales que fortalecieron, al igual que la ins-

21 Archivo de la Subdelegación de Putre (en adelante ASP), Oficios varios, foja 19, 1908.

22 AIT, Ejército y Armada, 1920, Nº 13.

23 Archivo Histórico Vicente Dagnino (en adelante AHVD), Oficios Recibidos, Comandancia General, Arica, 1915-1918, No 137.

24 ASP, Oficios varios, 1924, folio 19; AIT, Subdelegados, 1919, No 11.

25 AHVD, Oficios Recibidos, Comandancia General, Arica, 1915-1918, No 158.

26 AHVD, Oficios Recibidos, Comandancia General, Arica, 1915-1918, No 139.

27 AHVD, Oficios Recibidos, Comandancia General, Arica, 1915-1918, s/n.

28 AIT, Juzgado de Subdelegación, Tarapacá, 1916, Nº 28. ASP, Subdelegación, 1924, oficio № 3.

29 AHVD, Comandancia de Armas, Arica, 1916, N 223.

30 AHVD, Oficios Recibidos, Comandancia General, Arica, 1915-1918, No 163.

31 AHVD, Ministerio de Industria y Obras Públicas, 1900, Nº 889.

32 AHVD, Oficios Recibidos, Comandancia General, Arica, 1915-1918, Nº 182.

33 AHVD, Intendencia de Tacna, 1921, volumen 66. 
trucción escolar, la identidad nacional en el norte de Chile, desde las tradiciones cívico-militares ${ }^{34}$.

\section{SOLDADOS Y MÚSICOS EN LOS CUARTELES}

La reingeniería castrense requirió de una reestructuración de la jerarquía interna, generando transformaciones en el adiestramiento de la oficialidad sobre procedimientos, maniobras, estrategias, tácticas y manejo e implementación de nuevos armamentos. Este plan de innovación también precisó de servicios que debían ser asumidos por la suboficialidad, siendo a su vez instruidos en el moderno quehacer militar $^{35}$.

Los vertiginosos cambios que experimentó el Ejército, en cuanto a su organización, logística y equipamiento, buscaron aplicar al pie de la letra el modelo prusiano; incluso se reprodujeron los uniformes, los pickelhaube, las armas, marchas e himnos militares ${ }^{36}$, con el objetivo de replicar la doctrina y perfil profesional del soldado alemán ${ }^{37}$.

En términos prácticos, con la reforma institucional funcionando, se necesitó un diversificado contingente que no solo dominara los armamentos, sino que fuera capaz de asumir los diferentes tipos de oficios que el nuevo sistema logístico castrense requería, como sastres, mecánicos, electricistas, practicantes, cocineros y músicos, entre otros.

Tal como en los ejércitos europeos, rápidamente se incorporó el moderno formato musical para la congregación de las tropas y para acompañar el desplazamiento de los soldados. A la ya tradicional "banda de guerra", cuya base estaba compuesta por músicos que interpretaban membranófonos (bombo y tambor) y aerófonos (como pitos, clarines o cornetas), se agregó un segmento de músicos que dominaba variados aerófonos de "metal o de bronce" polifónicos, para conformar la "banda instrumental".

La incorporación de aerófonos de bronce con pistones o válvulas, cuya morfología facilitaba la interpretación de la música en movimiento (como trombones, trompetas, tubas, etc. $)^{38}$, permitió que los desfiles o el traslado de la infantería

34 Claudio Aguirre y Alberto Díaz, "Monumentos, fiestas y desfiles en Iquique. Nacionalismo en 1900, patrimonio en el 2000", en Si somos Americanos VII:2, 2006. La importancia simbólica de los héroes en William Sater "Arturo Prat, símbolo de ideas nacionales ante la frustración chilena", en Mapocho, V:4, Santiago, 1966; Sergio González Miranda, "El símbolo de Prat en la mentalidad popular tarapaqueña durante el ciclo del salitre", en Si somos Americanos, V:4, Iquique, 2003.

35 William Sater y Holger Herwig, The Grand Illusion. The Prussianization of the Chilean Army, Lincoln, University of Nebraska Press, 1999.

36 Ferenc Fischer, El modelo militar prusiano y las Fuerzas Armadas de Chile 1885-1945, Pécs, University Press, 1999.

37 Enrique Brahm García, "Del soldado romántico al soldado profesional. Revolución en el pensamiento militar chileno. 1885-1940", en Historia 25, 1990, 5-37.

38 Un punto de inflexión en la historia de las bandas, fue el invento de los alemanes Heinrich Stölzel y Friedrich Bluhmel, quienes incorporaron en 1818 válvulas a los aerófonos de bronce. Con los años se fabricaron varios instrumentos capaces de proyectar el sonido en espacios abiertos con una 
fueran engalanados por marchas que contenían atractivas melodías, armónicos compases y cadencias musicales compuestas en Europa en el siglo XIX. Las marchas militares tuvieron a Richard Wagner como punto cardinal en este tipo de composiciones musicales, melodías que ciertamente enfatizaban el nacionalismo entre los países europeos ${ }^{39}$.

Siempre atento al modelo alemán, en 1901 el Ejército reguló la dotación de músicos de las bandas militares, decretando que:

“ $1{ }^{\circ}$ Autorizase a los comandantes de los cuerpos de Infantería del Ejército para destinar hasta cinco plazas de soldados en cada compañía, además de la plaza del sarjento $1^{\circ}$ jefe de banda i de las seis plazas de cornetas-músicos de la Plana Mayor, para que sean ocupadas por individuos destinados a la banda de músicos del respectivo cuerpo [...]

$3^{\circ}$ Los músicos servirán principalmente como cornetas o tambores para los servicios de guardia i otros, cuando fueren necesarios, i no se les sentará plaza a ninguno que no acepte la condición anterior" ${ }^{40}$.

Conjuntamente, se precisaron los tipos de bandas instrumentales de los distintos batallones, disponiendo que las "bandas de músicos para los cuerpos del Ejército serán de dos clases: de caballería, de artillería o fanfarra i de infantería o armonía" ${ }^{41}$. El instrumental de las agrupaciones de caballería y artillería fanfarria debía estar conformado por los siguientes aerófonos: 2 bugles quintos, 1 bugle solo si $b$, 1 bugle II, 2 bugle II, 2 bugle III y IV, 1 corneta pistón solo I, 1 corneta pistón I si b, 2 corneta pistón II do, 6 quintos, 1 barítono solo I, 1 barítono II, 1 tuba solo I, 3 trombones de pistones, 4 trompetas mi b, 4 contrabajos si b mi b y 1 helicón ${ }^{42}$. En este caso, la cantidad de músicos corresponde a 33. Sobre las bandas destinadas a la infantería se dispuso que

"en cada batallon habrá una banda de veinticinco músicos, que podrá aumentarse o disminuirse según las circunstancias; debiendo sus individuos hacer parte de la fuerza efectiva de todas las compañias, sin que la calidad de músicos impida que sean instruidos en el manejo del arma i demas obligaciones del soldado; formará unida a la de tambores a las órdenes del tambor mayor, i tanto en guarnicion como en campaña alojarán siempre juntos" 43 .

masiva presencia de personas, como calles, plazas o avenidas, pero no existía un instrumento de tonalidad grave (bajo o barítono), con la suficiente potencia para dar una base tonal adecuada al resto de los instrumentos de la banda. En 1835, Friedrich Wilhelm Wieprecht fue quien introdujo la tubabajo, para armonizar una banda instrumental que interpretara sinfonías mientras marchaban las tropas. Véase Richard Cohen, The musical society community bands of Valencia, Spain: a global study of their administration, instrumentation, repertorie and performance activities, Tesis Doctoral, Universidad de Northwestern, Oxford, 1997; José Brufal Arráez, Estudio de la trayectoria en educación musical de los componentes de sociedades musicales de Alicante: Vega Baja, Medio y Alto Vinalopó, Tesis Doctoral, Universidad de Alicante, Alicante, 2008.

39 Véase Ernest Gellner, Naciones y Nacionalismo, Cambridge, Madrid, 1983; Eric Hobsbawm, Naciones y nacionalismos desde 1780, Barcelona, Crítica, 1992.

40 Ordenanza Jeneral del Ejercito, op. cit., II:28.

41 Ibid., 15.

42 Idem.

43 Ibid., 16. 
Los instrumentos requeridos para la infantería eran: 1 flauta en do, 1 flautín en re b, 1 requinto, 6 clarinetes si b, 1 clarín bajo si b, 1 saxofón soprano si b, 1 saxofón alto mi b, 1 saxofón tenor si b, 1 saxofón barítono mi b, 1 bugle quinto, 2 bugles si b, 2 cornetas pistón si b, 2 trompetas mi b, 3 trombones de pistones do, 2 cornos mi b, 4 quintos mi b, 2 barítonos, 1 tuba solo si b, 2 bajos si b, 1 contrabajo si b, 1 contrabajo mi b, 1 batería y 1 lira ${ }^{44}$. Estos destacamentos con una gran cantidad de músicos fueron utilizados en diferentes eventos cívico-militares a lo largo del territorio nacional.

Aunque esta estructura que regulaba a las bandas de la tropa abrió con los años escenarios de discusión interna, debido a que habían ingresado contratados algunos músicos revoltosos, que anhelaban "actos aparatosos i brillantes", se justificaban apelando a que eran parte vital en la figuración pública de las unidades castrenses, siendo considerados como "los hijos mimados, sobre los cuales no puede caer la vara de la justicia ni de la disciplina". "Ser músico i no ser indisciplinado i borracho" 45 constituía su identidad corporativa. No obstante, surgieron tempranamente voces disonantes sobre las conductas de los músicos, ya que la calidad artística o sus aspiraciones sociales no debían alterar el ethos de la rigurosa disciplina militar, la cual debía acrecentar un espíritu patriótico reflejado en los actos privados y públicos del soldado. En 1914, el capitán Alberto Muñoz decía que las

"bandas militares deben ser solo militares, es decir, cada músico debe ser tan buen soldado como el mejor de los soldados de un rejimiento. La banda debe acompañar a la tropa a todas partes, al campo de ejercicios, a las maniobras, a las concentraciones, a la guerra, i debe morir tan bravamente como sabe morir el soldado que lleva un fusil para combatir" 46 .

Esta perspectiva panóptica sobre los músicos se proyectó en todas las zonas militares del país, exigiéndoles un buen comportamiento, pese a su origen social, y compromiso en diversas actividades que la sociedad requería. Bajo esta impronta, se intentaba forjar, desde los cuarteles, a los "soldados-ciudadanos" 47.

44 Idem.

45 Alberto Muñoz, "La banda de músicos. ¿Disciplina o música”, en Memorial del Estado Mayor del Ejército de Chile, XI:IX, Santiago, 1914, 775.

${ }^{46}$ Muñoz finaliza su artículo sentenciando que "tenemos hoi dia algunos músicos tan gordos, que ocupan dos hileras en vez de una, i que solo pueden tocar en una retreta, i eso... si se les da plata para carro". Ibid., 776.

47 El 28 de octubre de 1941 se aprobó el Reglamento Orgánico del Curso de Aspirantes a Músicos, con el fin de formar músicos idóneos para las bandas instrumentales del Ejército y perfeccionar la preparación profesional de los jefes de bandas y del personal de músicos; así se funda aquel año la Escuela de Músicos Militares. Para 1945, la normativa fue modificada por el Reglamento Orgánico y de Funcionamiento de la Escuela de Músicos Militares. La organización contemplaba: a) Cursos regimentados: formados por conscriptos de los regimientos y escuelas de Armas, a cargo de los jefes de bandas respectivos. b) Cursos especiales: de perfeccionamiento, para personal de planta contratado (de 5 meses de duración). c) Cursos de aspirantes a músicos: de personal reclutado, previo examen de selección. Nuevos cambios se dan a partir del 3 de febrero de 1949, debido a que fue aprobado el Reglamento Orgánico de la Escuela de Músicos Militares, quedando solo los cursos de aspirantes a músicos y de perfeccionamiento. Paradójicamente, esta estructura sufrió una modificación el 17 de septiembre de 1951, considerándose solo los cursos: a) I ciclo, para soldados aspirantes a músicos; b) 
Con la responsabilidad de entrelazar vínculos con la sociedad civil, en Iquique, los músicos del batallón Carampangue y del regimiento Húsares debían recorrer el puerto tocando diferentes himnos marciales y reverenciar con sones a la Sociedad de Veteranos del 79, como parte de las solemnidades dedicadas a los héroes del 21 de mayo, generando un ambiente de fervor nacional ${ }^{48}$. Además, se comprometían cada año a ensayar los cánticos patrióticos en las escuelas nortinas y acompañar los desfiles escolares ${ }^{49}$. Conjuntamente, formaron orfeones para interpretar diferentes temas en los quioscos de las plazas nortinas ${ }^{50}$. Para las fiestas patrias celebradas en Tacna en 1921, "200 hombres de los Regimientos Rancagua, Lanceros y Velásquez y 100 del Batallón Zapadores, con sus bandas de músicos" participaron en todas las actividades programadas, finalizando con la "Parada militar en el Club Hípico" de esa ciudad ${ }^{51}$. En las fiestas patronales de los poblados cordilleranos, se dispuso que se izara el pabellón patrio, se cantara el himno nacional y el de Yungay, y se acicalaran las aldeas con el tricolor chileno ${ }^{52}$.

Con los nuevos sonidos de la bandas instrumentales de los regimientos, el país fue testigo de los cambios que experimentó el Ejército, resonando en las calles del territorio los compases de las tradicionales marchas a paso ligero de "Van der Krafft", "Inglaterra y Prusia", "Recuerdos de 30 años", "Ich hatt' einen Kameraden" (Uhland y Silcher), "Bayrischer Defiliermarsch" (Scherzer) y "Los Nibelungos” de Richard Wagner. Estas melodías, más los uniformes, pickel, cascos y armamentos, simbolizaban a una institución que intentó mimetizarse con el prototipo militar alemán y erigirse como "los prusianos de Sudamérica" 53 .

\section{SOLDADOS, INDÍGENAS Y BANDAS DE BRONCE}

Desde una perspectiva social, la reestructuración del Ejército facilitó el ingreso de soldados "clase", sin rango, que fueron contratados como músicos una vez que habían cumplido con el servicio militar ${ }^{54}$. En tal contexto, este fue visto como una atractiva alternativa laboral, que posibilitó en parte la descompresión socioeconómica de algunos segmentos vulnerables de la sociedad nacional, entre ellos los campesinos andinos, que buscaban la seguridad laboral y la estabilidad

II ciclo, para cabos músicos, instrumentistas; c) III ciclo, para sargentos $2^{\text {os }}$ músicos, como instrumentistas, solistas o jefes de bandas; y d) otros cursos que disponga la comandancia. Véase Memorial del Ejército de Chile LIV:299, Santiago, 1960, 57.

48 El Nacional, Iquique, 20 de mayo de 1904.

49 AIT, Ejército, Armada y Carabineros, Tarapacá, 1911, No 43.

50 Ovalle, op. cit, 253.

51 AHVD, Intendencia de Tacna, 1921, volumen 66.

52 ASP, Oficios varios, 1951.

53 Esta expresión fue acuñada por el periódico francés Le Temps, el 27 de diciembre de 1914, donde exponen sobre "los chilenos de sentimientos jermanófilos" y la "manifestación jermanófila de los militares chilenos"; además publican que "los enviados de Guillermo II proclamaron que la sola vaya alemana ha recibido el don, el privilegio de saber enseñar y que iban a sacar a Chile de la barbarie", texto reseñado en El Ferrocarril, Arica, 3 de mayo de 1915.

54 Diario Oficial de la República de Chile, 5 de septiembre de 1900. 
familiar en sus localidades de origen, amén de la impronta y del compromiso patriótico. Una segunda lectura nos remite a reflexionar acerca de que el alistamiento no solo fue una opción laboral, sino que también fue un medio para los comuneros, que, al integrarse a la tropa, articularon mecanismos de legitimidad ante la sociedad chilena.

En otro ámbito, cuando se generaron momentos de crisis económica, como la 1929, en el norte del país el Ejército desplegó una serie de redes institucionales para reinsertar laboralmente a ex soldados músicos, quienes, una vez pasados a retiro, habían sido contratados por las filarmónicas de las oficinas de las salitreras, quedando cesantes por la mentada crisis ${ }^{55}$.

A medida que avanzaba el siglo XX, con ciertos avatares, los comuneros andinos lentamente se fueron alistando, influenciados quizás por la atmósfera chilenizadora o motivados por opciones laborales concretas, lo que significó que campesinos indígenas ingresaran a los cuarteles, proviniendo desde diferentes pisos ecológicos y comunidades ${ }^{56}$.

En tal sentido, con la experiencia militar de la vida en los regimientos, algunos de los indígenas eligieron el camino de la contratación como músicos de infantería; estos, ya ejecutaban diferentes aerófonos tradicionales andinos, como lacas, sikuras, pinkillus, lichiwayus o tarkas ${ }^{57}$, lo que facilitó el aprendizaje de las técnicas de interpretación de los instrumentos de metal y los llevó incluso a instruirse en la lectura musical para interpretar himnos y marchas. Estos "sopladores" se fueron instruyendo en la ejecución de los aerófonos de bronce (trompetas, tubas, bajos) y

55 AIT, Funcionarios públicos, Tarapacá, 1931, Nº 3. Entre algunas negativas, una respuesta venida desde Angol anunciaba que "se ha producido una vacante de músico, contrabajo mi-bemol, en el Regimiento 'Husares' de esta ciudad.- Expresa, además, el señor Comandante, que si hubiera un músico de esta clase entre los que han quedado cesantes en las Oficinas salitreras de la Provincia de Tarapacá, podría ser contratado para la citada Unidad, siempre que acreditara haber hecho efectivamente el servicio militar y haber sido licenciado con buena conducta". Ibid., 22 de junio de 1931, № 3.

56 En el área de Tarapacá, para 1919, se registraron 49 reclutas andinos (AIT, Subdelegaciones, Tarapacá, 1921); y en los alrededores de Arica, en 1920, se enrolaron 266 comuneros (Arbitraje entre Perú y Chile, Réplica del Perú en el litigio que, emanado de la Cuestión del Pacífico, se sigue ante el Presidente de los Estados Unidos de América como Arbitro, Whashington, s.e., 1924).

57 Las lacas son aerófonos de filo, sin canal de insuflación, cuya denominación tradicional ha sido la expresión latina "zampoña". Este instrumento se toca en agrupaciones conocidas como laquitas y acompaña fiestas patronales, diferentes ritos y actividades comunitarias (matrimonios, bautizos, día de Difuntos, etc.), tanto en la precordillera como en el altiplano y en las ciudades nortinas. Las sikuras son aerófonos típicos de la zona de Isluga y Cariquima (estéticamente parecidas a las flautas de pan, pero diferente a las lacas, siendo tocadas en conjunto de sikuriadas para las fiestas patronales de San Juan y Santo Tomás en el altiplano. Los pinkillus son aerófonos con boquilla, que se utilizan en el altiplano para la temporada estival y la celebración de la anata de carnaval, acompañándose de una bandola (cordófono) y cantores de coplas. Los instrumentos de caña conocidos como lichiwayus se tocan en grupos para la fiesta de las Cruces y en algunas festividades patronales, tanto en la precordillera como en el altiplano. Las tarkas son aerófonos introducidos a comienzo del siglo XX por trabajadores bolivianos que llegaron a laborar a las azufreras al interior de Arica. Se tocan para el tiempo de carnaval. En poblados como Chiapa, para la fiesta de los Pastores del 6 de enero (fiesta de Reyes o Pascua de los negros, como también se conoce), se tocan quenas de bronce de 5 orificios, para acompañar con una caja y un bombo al baile de pastores; la inclusión de quenas de este material debe ser de fines del siglo XIX, con influencia de la actividad salitrera. Una descripción detallada y técnica de los instrumentos andinos, en Alberto Díaz Araya, "Toquen, soplen sin parar. Antecedentes etnomusicológicos de las lacas tarapaqueñas”, en Percepción 2, Arica, 1998, 73-94. 
en los arreglos musicales, técnica que con los años fueron depurando, hasta alcanzar un reconocido nivel musical, como fue el caso de los soldados músicos de los poblados tarapaqueños de Mamiña ${ }^{58}$ y Guaviña ${ }^{59}$.

Al asumir la carrera de músico de batallón, con el tiempo pudieron ascender en grados militares, llegando a la jerarquía de suboficiales, estatus castrense que actuó como mecanismo de prestigio social a nivel comunitario, consiguiendo ser valorados por sus cualidades artísticas a nivel nacional ${ }^{60}$.

Hay casos de comuneros que, a la vez que ejercían labores de músico en el Ejército, desarrollaron paralelamente una carrera académica, amplificando los espacios donde podían desenvolverse socialmente las poblaciones andinas en el norte de Chile ${ }^{61}$.

En tal tenor, ¿cómo repercutía en las comunidades andinas que campesinos indígenas se enrolaran como parte del proceso de conscripción y contratación de contingente militar? Como advertimos, los campesinos que habían realizado el

58 José María Caro recuerda que cuando fue sacerdote en la parroquia de Mamiña, a comienzos del siglo XX, en el poblado había una "buena banda de músicos, que daba gran realce a la exterioridad de las fiestas [...] [agrega que], salieron grandes músicos, y directores de banda en Bolivia y en Tarapacá. Años después aquellas bandas se repartirían, aun fraccionándose, por los pueblos u oficinas de la pampa, para solemnizar el 18 de Septiembre u otras fiestas". Joaquín Fuenzalida Morandé (ed.), El Cardenal Caro: Autobiografía del eminentísimo y reverendísimo, señor Cardenal de D. José María Caro Rodríguez, primer Cardenal chileno: Apuntes y recuerdos, Santiago, Impresores Carrión e hijos, 1968, 46-47. Bèze, en 1920, corrobora las apreciaciones musicales del Cardenal Caro, señalando que Mamiña "cuenta con un club social y una banda de músicos de 30 miembros provista de excelente instrumental, presta su concurso a fiestas populares y de caridad". Francisco de Bèze, Tarapacá en sus aspectos físico, social y económico, Santiago, Imprenta Universo, 1920, 84. Músicos mamiñanos (ex soldados) de las familias Caqueo, Luza, Bacián, Capetillo o Estica fueron reconocidos tempranamente como "maestros" en la ejecución de los bronces. En varios desfiles estos eran contratados por las distintas guarniciones para que acompañaran a la banda, pese a que estaban en retiro.

59 Músicos recordados de Guaviña, como Guillermo Platero Guajo (suboficial del regimiento Carampangue, Iquique), Humberto Platero Álvarez (suboficial de la Marina), Eugenio García (suboficial del Ejército). Sergio Platero Chambe, "Cosmovisión Andina IST'APXAM, Tradiciones musicales Aymaras", en Sunipatqhanawi, Iquique, CONADI, Subdirección Norte, 1999. Otros músicos guaviñanos ex militares, como Ignacio Zamora, Andrés Paltero, Francisco Jachura, Roberto García, Nasareo Cruz, Víctor Jaiña, Juan Jachura, Fidel Palape, José Chire, Ramón Jaiña y Severo Zamora, fueron registrados por Mauricio Salazar Pincheira, Primer registro histórico fotográfico de los Aymaras de provincia de Iquique, Iquique, Oñate Impresores, 2002, y Registro histórico fotográfico de la provincia de Iquique (1900-1950), Movimiento Gráfico, Iquique, 2004.

60 Tal es el caso del autor del himno a Iquique, don Victoriano Caqueo Cholele, músico oriundo de Mamiña, el cual señala "que una de las etapas más importante de su vida, comenzó cuando le correspondió realizar el Servicio Militar en el ex Regimiento Granaderos. En 1931 ingresó a la unidad como cabo primero músico y posteriormente fue seleccionado para integrar la banda de la Escuela Militar [...] el año 1942, obtuvo el primer puesto con la Marcha de Lanceros Avanzando. En tanto en 1949 obtuvo el primer puesto con el Himno de Tarapacá. En 1960 y por orden del Decreto Supremo 2.149, después de pasar 35 años en el Ejército, se acogió a jubilación con el grado de brigadier, hoy suboficial mayor", La Estrella, Iquique, 17 de diciembre de 2002 (reportaje). El destacado es nuestro. Victoriano falleció el 6 de agosto de 2005, a los 104 años.

61 Es conocido el caso de Manuel Mamani Mamani, músico aymara instrumentista de trompeta, arte que aprendió en su localidad de Guallatire, en la cordillera ariqueña. Potenció su técnica interpretativa cuando realizó el servicio militar en la década de 1940, llegando posteriormente a ser director de la banda del regimiento. Además, estudió para profesor de Música y obtuvo un Master of Arts (Anthropology) en Estados Unidos. 
servicio militar o que estaban contratados como soldados reprodujeron a nivel comunitario las bandas instrumentales de los regimientos ${ }^{62}$.

Este paso significó que, durante las primeras décadas del siglo XX, surgieran entre cuarteles y poblados andinos las bandas de bronce, agrupaciones que congregaron a músicos de los batallones con intereses en común, para participar principalmente en las ceremonias religiosas del pueblo ${ }^{63}$.

Los músicos de las bandas de bronce incorporaron a sus prácticas culturales comunitarias nuevas expresiones musicales, como marchas o pasacalles, para acompañar procesiones, himnos marciales y religiosos en honor a los santos patronos, fanfarrias (dianas en la versión local), para destacar ciertos momentos rituales o festivos, y adaptación de melodías y ritmos tradicionales (como huaynos) a la interpretación con instrumentos de bronce, para amenizar las celebraciones en la casa del alférez o en el parabién (local).

Consignemos que, para integrar las bandas a las ceremonias, fue relevante la figura social del alférez, que abrió el espacio cúltico para legitimar a la banda de músicos. De no ser así, la banda habría estado vinculada solo a desfiles o eventos, y no a musicalizar las costumbres indígenas. Problematizando este argumento, el alferazgo correspondía a un cargo religioso de origen colonial (que apela a una denominación militar), que asumía la totalidad de los gastos de la festividad en

62 Las bandas de bronce o bandas de música son un fenómeno social que está presente en diferentes poblaciones indígenas, campesinas o aldeanas de Latinoamérica y Europa, cada una con matices culturales e históricos propios, influenciadas por elementos externos, como las expresiones militares. Cfr. Cohen, op. cit. y Brufal, op. cit. Los casos de bandas en Bolivia y Perú responden a iguales características que las chilenas, ya que la influencia musical alemana gravitó en el surgimiento de estas en los tres países, respondiendo cada una a contextos sociohistóricos particulares. Por ejemplo, Ernesto López Mindreau, peruano nacido en Chiclayo, fue instruido como músico en Alemania y Estados Unidos, llegando a ocupar en 1927 el cargo de Director Superior de Música del Ejército peruano y, posteriormente, asumiendo la dirección de la banda de la Guardia Republicana, aunque el Ejército peruano tenía influencia francesa en su reorganización, desde 1896. Entre otros estudios, véanse Román Robles Mendoza, La banda de músicos: Las bellas artes musicales en el sur de Ancash, Lima, Universidad Nacional Mayor de San Marcos, 2000; Raoul y Marguerite D’Harcourt, La música de los incas y sus supervivencias, Lima, Occidental Petroleum Corporation of Perú, 1925; Raúl R. Romero, "Cambio musical y resistencia cultural en los Andes centrales del Perú", en idem, Música, danzas y máscaras en los Andes, Lima, Pontificia Universidad Católica del Perú, 1998; y Alberto Díaz Araya, "De acordes andinos al ritmo chileno. Los músicos aymaras durante las primeras décadas del siglo XX en el área de Arica”, en Percepción 3/4, Arica, 2000, 75-92.

63 Las ceremonias religiosas andinas llamaron la atención, por los ritos, el jolgorio y la música, a numerosos viajeros y expedicionarios que recorrieron la zona cuando fue incorporada a Chile; al respecto, véanse las descripciones, entre otros, de Alejandro Beltrán, Departamento de Tarapacá. Aspecto general del terreno, su clima i sus producciones, Santiago, Imprenta de La República, 1879, 23; Isaiah Bowman, Los senderos del desierto de Atacama, Santiago, Sociedad Chilena de Historia y Geografía, 1942 [1924], 92; Bèze, op. cit., 69. Es necesario señalar que en las fiestas patronales, aparte de la participación de comparsas de laquitas, también habían grupos llamados "orquestas", que interpretaban música tradicional (huaynos y coplas) con acordeón, guitarra, violín, mandolina o quenas. Aún pueden verse las orquestas para fiestas de las Cruces, ritos para la siembra de la papa (pachallampe) o tocando coplas de carnaval. Desde fines de la década de 1970, se introdujeron en las fiestas las orquestas electrónicas, para acompañar las cumbias andinas y la versión limeña de la cumbia "chicha" en el local del pueblo; hacia mediados de la década del 90, grupos electrónicos de cumbia andina, provenientes desde Iquique y Arica, se trasladaron a Santiago, siendo popularizados como grupos sound. 
honor al santo patrono de un poblado, como la comida, bebidas y grupos musicales que asisten, como bandas de bronce o comparsas de laquitas; en términos simbólicos, representaba a la comunidad frente a los ritos religiosos ${ }^{64}$. El alferazgo como sistema de cargo podía ser asumido individual o colectivamente, debido a que la alternancia del cargo posibilitaba dicha movilidad, no restringiéndose a una sola persona, sino más bien operando como un sistema dinámico en términos de participación particular o corporativa, dependiendo de los contextos sociales, culturales o económicos de las comunidades ${ }^{65}$.

Otros cargos comunitarios son el mayordomo, encargado de la vestimenta, de la imagen del santo y de su ritualidad; el fabriquero, que asume las llaves, objetos y ornamentación del templo (de "fábrica"); el sacristán, que asiste la ritualidad de la liturgia, y los "cantores", que interpretan cánticos religiosos como las "salve", cantos a la Virgen, a la Cruz de mayo ${ }^{66}$ o al "Señor" (Espíritu Santo) ${ }^{67}$.

64 Contextualizando históricamente, el sacerdote Luis Urzúa expone sobre la fiesta de la Asunta en Putre, durante la primera mitad del siglo XX, señalando que "el personaje principal de la fiesta patronal es el alférez, que pide ese cargo el año anterior y toma la responsabilidad de correr con todos los gastos de que se presenten: traída del sacerdote y de banda de músicos y servicio de almuerzo a todo el pueblo con abundancia de carne de llamo, cordero y aves, además de generosas libaciones de vino de Codpa, que recibe el nombre de pintatani por el lugar donde originalmente se producía. Es de rigor iniciar la festividad con una ceremonia que se llama 'levantamiento de las velas', a la caída de la tarde. El alférez hace abrir los cajones de que se ha provisto de antemano en Arica, la reparte entre los vecinos y se forma una procesión hasta el templo precedida de banderas y estandartes, con banda de zampoña y de instrumentos de bronce, petardos, cohetes y repiques de campanas". Luis Urzúa, Arica, puerta nueva, Santiago, Editorial Andrés Bello, 1957, 85-86. El destacado es nuestro.

65 José María Caro, a inicios del siglo XX, describía que en los pueblos andinos "cada año se eligen o renuevan los Alféreces de los Santos, y de las fiestas con que los honran los pueblos y los devotos, que suelen acudir hasta de muy lejos. Como en todas partes, tampoco faltan quienes vayan a esas fiestas simplemente por motivos mercantiles, o por curiosidad o distracción. El Alférez se hace cargo solemnemente de su investidura, recibiendo del cura el estandarte Santo, y en esa ocasión, lo acompaña la esposa, si la tiene, o su madre; y con ello queda comprometido a prepararse para la fiesta del año venidero, juntando recursos para sus gastos, en que los que se cuentan el honorario del cura [...] el de los cantores y músicos y lo necesario para el almuerzo de todos, especialmente el alcohol o chicha de maíz; almuerzo, al que muchas familias concurrían, aportando también su contribución de alimentos. La chicha se fabricaba a modo de la región, masticando las mujeres el maíz, y echándolo en la paila o cántaro para su fermentación. Se usaba carne de cordero o de machorra (llamo). Solían hacer un plato muy apreciado en el Perú llamado calapurca, especie de puchero, cocido con una piedra de río en la olla, que parece le comunica especial sabor, y con mucho ají; el cual, naturalmente, provoca mucho el apetito de la chicha, por el ardor que deja en la boca y en el estómago. En estas fiestas era muy difícil la recepción de otros sacramentos, fuera del bautismo de las guaguas, y tal vez algún matrimonio, porque la ocupación de las fiestas, la bullanga de música, y los estampidos de las camaretas (tiros de dinamita en rocas cercanas al pueblo) absorbían la atención, y alejaban otro pensamiento de aquella gente, por lo general infantil; fuera de que los hombres sabían que difícilmente se iban a medir, en el uso del fuerte o de la chicha: el costumbre, como decían, de celebrar la fiesta había que conservarlo. Solían juntar en la misma ocasión las fiestas de todos los santos de la iglesia del pueblo, para poder dispersarse después a los pastoreos, cultivos de la tierra, trabajos en la oficinas salitreras, o arreos, y no tener que hacer otra vez en el año, ese paréntesis de su vida, para muchos costoso y casi imposible". Fuenzalida, op. cit., 46.

66 AHVD, Subdelegados, 1923, volumen 70, oficio $\mathrm{N}^{\circ} 18$

67 El sacerdote Julio Ramírez, durante la década de 1920, realizó una visita a la sierra ariqueña, detallando algunos aspectos sobre los sistemas de cargos en el valle de Codpa. A decir de los juicios de Ramírez, "hay piedad natural, conciencia recta y el deseo ardiente de honrar a la Divinidad y además a los amigos en esas fiestas siempre precedidas de una Misa Solemne y de pintoresca procesión, encabezada por el Mayordomo que es el vecino encargado de cuidar la Iglesia por el año entero, 
Los sacerdotes, misioneros o capellanes acudían a los poblados cordilleranos "en mui contadas épocas del año, solamente cada vez que alguna Comunidad de indíjenas celebra su fiesta relijiosa", como se exponía en Chislluma en $1924^{68}$. Siguiendo el calendario litúrgico y santoral, recorrían un circuito de varias comunidades relativamente cercanas, en la sierra o en el altiplano, así como también bajaban desde el portezuelo de Chapiquiña a "Pachama, donde se escuchan músicas marciales, repique de campanas, estampidos de petardos y, en medio de toda esta algazara, una multitud pintoresca acompaña las andas del santo"69. Todos, sacerdotes y músicos, eran invitados por los alféreces, quienes también cancelaban los estipendios por los servicios.

En un plano musical, los aerófonos de bronce, tal como en los batallones, generaban potentes sonidos que resonaban en todos los rincones del poblado, destacando la presencia de esta agrupación que permitió congregar, en torno a la música, el simbolismo y la ritualidad, a los comuneros dispersos en los campos de cultivos o llanuras. Incluso, a la entrada del alférez al pueblo o en varios pasajes de la festividad (entrada de cera, invitación a las liturgias, comer kalapurka o llevar a los feligreses al local), estos siempre se acompañaban de una banda de bronce ${ }^{70}$.

\section{BANDAS DE BRONCE EN LOS ANDES}

Si durante las primeras décadas del siglo XX fue significativa la integración de las expresiones musicales castrenses a las costumbres andinas, entonces fue oportuno a nivel comunitario formalizar las agrupaciones, además de implementarlas

mientras dura su gobierno: cargo en conciencia y ad honorem que se viene sucediendo desde tiempos inmemoriales. También el alférez, cargo honorífico y pío, tiene parte principal en esas fiestas, pues a quien debe costearlas de su peculio y pagar desde la cera hasta la chicha de jora, y los picantes para los romeros e invitados [...] Al comenzar el año, la autoridad, precedida por el Tata, elige a los vecinos caracterizados, y por turno, para los alferazgos de la temporada: patronos de los santos protectores que "correrán la fiesta" para atraerse la protección del cielo; y suele acontecer lo que en grandes ciudades de alta cultura: la sangrienta lucha por lucir, por desplegar todo el lujo imaginable para aplastar al rival, y que la fiesta resonante de un alférez hunda al otro, aunque el rumboso señor quede despellejado y maltrecho con más deuda que sentimientos". Julio Ramírez, Tierras Grises, Arica, Putre, Socoroma, Tignamar, Codpa, Santiago, Imprenta La Tracción, 1931, 132-133.

68 AHVD, Subdelegados, 1924, oficio No 74.

69 Urzúa, op . cit., 139.

70 En 1923 el Cardenal Caro relató que en la fiesta de San Andrés de Pica, después de la misa con los alféreces, "siguió la procesión, con la estatua del Santo y de San Antonio, por las calles de la población con acompañamiento de la Banda de Músicos y del pueblo y en medio de los estampidos de las bombas [...] De ahí se fueron a celebrar el parabién o sea el almuerzo y la fiesta en común con el dinero colectado con lo que cada familia aporta; parabién que es tal vez el único lunar de la fiesta por el exceso en la bebida en que muchos incurren". Carolina Figueroa y Benjamín Silva, Documentos para la historia regional: Visitas pastorales de las parroquias de la Provincia de Tarapacá (19221926), José María Caro R. Obispo de Milas y Vicario Apostólico de Tarapacá, Santiago, Universidad Santo Tomás-CEIP Ediciones, 2008, 40-41. Del mismo modo, para la fiesta de Tarapacá: "como en años anteriores con todo entusiasmo se han iniciado los preparativos para celebrar la fiesta de San Lorenzo, el día 10 de Agosto próximo, en el pueblo de Tarapacá. Se está preparando la Iglesia para recibir a los feligreses en la mejor forma, se ha contratado una buena banda de músicos de Pica que amenizará los diferentes actos sociales y religiosos”. El Tarapacá, Iquique, 9 de agosto de 1945. 
con instrumentos. Como una muestra, los músicos de pueblos como Esquiña y Sucuna organizaron una banda con 16 instrumentos de metal, siendo contratados, entre otras, para la fiesta de San Santiago de Belén o para la fiesta de San Juan Bautista de Timar, donde "concurren peregrinos de Arica y Codpa; bandas musicales de Esquiña y Sucuna acompañan las procesiones y ensordecen el valle con sus ecos, unidos al estruendo de dinamitas, petardos y cohetes" ${ }^{\text {"71. }}$.

En otros casos, había comuneros que eran soldados en servicio activo que poseían trompetas o trombones y que los destinaban a la banda; pero, como existía interés entre comuneros más jóvenes por aprender la ejecución, fue necesario en ocasiones generar petitorios a los regimientos de la zona por instrumentos "dados de baja".

Por ejemplo, el "Comité pro adelanto del sector de Caquena" dirigió a la comandancia del regimiento Rancagua, de Arica, una carta "tendiente a obtener los instrumentos de música necesarios para formar una banda instrumental. El contenido de esta solicitud revela el espíritu de progreso e iniciativa de los habitantes de Caquena, espíritu que por desgracia no se halla muy a menudo en las poblaciones de la cordillera"72.

Hacia fines de la década de 1950, el interés por contar con instrumentos de bronce para las bandas pueblerinas sobrepasó los recursos con los cuales contaba el Ejército, situación que las autoridades locales intentaron solucionar. Al respecto, el Centro Musical de Chiapa solicitó a la Gobernación de Pisagua la asignación de 6 instrumentos de viento, pero la misiva no obtuvo una respuesta positiva, ya que los instrumentos "dados de baja" disponibles para estos casos, habían sido entregados a los músicos de Camiña,

"no obstante este inconveniente les he contestado; que considero tan loable iniciativa, que dice comprometerse a dar tocatas gratis al Público, y siendo este una sana distracción y recreación del espíritu, haré gestiones para obtener la donación de otros tantos para satisfacer lo solicitado"73.

Al mes siguiente, los miembros del Centro Musical de Chiapa respondieron asertivamente que "dicha institución agradece la amable acogida a su solicitud y espera confiado las diligencias que se puedan hacer a su favor" 74 .

Las referencias anteriores manifiestan el interés por contar con estos instrumentos, que habían adquirido cierto atractivo para las comunidades, ya que representaban un bien simbólico para los pueblos que contaban con una banda comunitaria y otorgaban prestigio a la localidad que incluía los sonidos del bronce en sus celebraciones.

Como era evidente la atracción que despertaban estos conjuntos, se abrió la posibilidad de que, ante al ausencia de músicos o bandas en ciertos poblados, los

71 Urzúa, op . cit., 214.

72 ASP, Guías de correspondencia, 15 de enero de 1915, s.n.

73 AIT, Gobernación de Pisagua, 31 de marzo de 1959, s.n.

74 AIT, Subdelegaciones, 22 de abril de 1959, s.n. 
campesinos del altiplano colindante con Bolivia contrataran grupos o instructores provenientes de ese país. Así, en 1923, en el campamento de Choquelimpie, el ciudadano boliviano Felipe Choque solicitó al subdelegado de Putre la autorización para que ingresara hasta el campamento una banda de doce músicos, para solemnizar la fiesta de la Asunta, solicitud que fue aprobada ${ }^{75}$. El 17 de octubre de 1925, el teniente de carabineros de ese mismo pueblo fue informado de la autorización para que ingresara, por el paso cordillerano de Paquisa, una banda de músicos bolivianos, quienes eran traídos por Pablo Marca, mayordomo de la iglesia de Timalchaca, para conmemorar la fiesta del santuario en honor a la Virgen de los Remedios ${ }^{76}$.

Del mismo modo, Wenceslao Robles solicitó, el 4 de julio de 1928, a la Subdelegación que permitiera el ingreso por cuatro días a Caquena de doce músicos de nacionalidad boliviana, que traían sus correspondientes instrumentos de viento. Esta banda debía acompañar la festividad de Santa Rosa, patrona de Caquena. Robles argumentó que una vez terminadas las celebraciones, los músicos volverían a sus localidades ${ }^{77}$. La fórmula de contratar bandas bolivianas persistía hasta mediados de siglo, incluso

"los músicos de Sabaya y Guachacalla, que suelen acudir a las festividades religiosas de Belén o Putre, se manejan 50 o más kilómetros en sus bicicletas que dejan en la frontera. Cargan a sus espaldas los bultos de abrigo y comida o sus enormes instrumentos de bronce, y pedalean tan airosos y cómodos que pudieran causar envidia a Atahualpa"78.

Como anticipamos, este tipo de tendencias musicales, influenciadas desde fines del siglo XIX por la doctrina militar, existió de forma paralela en Bolivia y Perú, incorporando simultáneamente a las bandas, tal como lo hicieron los indígenas andinos chilenos. Esta experiencia análoga grafica el alistamiento de los segmentos campesinos en las nuevas estructuras de los ejércitos, producto de las reformas castrenses que los generales europeos impulsaron, para construir "una nación en armas".

Desde una mirada social, la incorporación de las bandas a las costumbres andinas respondió a una lectura comunitaria para adaptar la cultura militar a la tradición.

Reanudando la trama, los etnólogos franceses D'Harcourt, que visitaban el Callao en 1913, quedaron sorprendidos por los "cobrizos soldados indios", que tocaban sin partitura un tradicional pasacalle, triste para los "oídos europeos, pero seleccionado perfectamente para esos días de alegría". Tiempo después, en la fiesta de San Mateo en el valle del Rímac, escucharon a la banda del pueblo interpretando ritmos típicos con los bronces ${ }^{79}$. En la sierra peruana, para la déca-

ASP, Subdelegación, 1923, oficio $\mathrm{N}^{\circ} 21$.

ASP, Subdelegación, 1925, oficio No 107

ASP, Subdelegación de Putre, 1928, s.n.

Urzúa, op. cit., 170.

D'Harcourt, op. cit., 198. 
da de 1920, agrupaciones de ex soldados indígenas llamadas "cachimbos" recorrían las aldeas, ofreciendo acompañar con "huaynos alegres" festividades o diferentes eventos sociales ${ }^{80}$.

En la década de 1950, este estilo musical ya se había popularizado en todos los países andinos, siendo requeridas las bandas de metal para participar en variadas festividades tradicionales. En el altiplano peruano, solamente en el distrito de Acora, uno de los quince de la provincia de Puno, en 1956 fueron registradas 17 bandas de bronce que acompañaban fiestas y carnavales, además de musicalizar las coreografías de las cullahuadas, diabladas y llamerada ${ }^{81}$. Por esos años, en Llica (Bolivia), muchos músicos de las bandas locales, debido a su calidad, fueron contratados como instructores en diferentes poblaciones de la zona y en aldeas del interior del país ${ }^{82}$. Al respecto, Urzúa manifestaba que, en la cordillera ariqueña, "algunas veces las bandas son contratadas en Bolivia o lejanos caseríos del departamento. Los bolivianos caminan a pie más de cien kilómetros por los páramos, con tropas de llamos, insensibles al frío, la distancia, la falta de alimento o reposo nocturno"83.

Las comunidades que contaban con banda de bronce, debieron reorganizar sus actividades. Algunos de los músicos residían en las ciudades, sitio donde se encontraban los regimientos, otros trabajaban en las oficinas salitreras de la pampa y el resto del conjunto se encontraba en los pueblos o caseríos ${ }^{84}$, generando que, pese a la experiencia musical, debieran acordar días para ensayar antes de las celebraciones, concentrándose en los lugares donde residía la mayoría de los instrumentistas.

Como había otros pueblos con bandas, los alféreces de las festividades no necesitaban contratar músicos externos; sin embargo, las localidades que no poseían estas agrupaciones debían sortear los inconvenientes contratando a bandas de otros lugares ${ }^{85}$. En algunos poblados, las comparsas de laquitas asumieron, como antaño, la totalidad de los ritos.

80 Hildebrando Castro Pozo, Nuestra comunidad indígena, Lima, s/e, 1924. La denominación de "cachimbos" se refiere a que son conjuntos musicales ambulantes, compuestos por músicos (ex militares) que reciben un estipendio por sus interpretaciones. Robles, op. cit., 80. El término "cachimbo" en el Caribe se relaciona a un tipo de "pipa", pero en el contexto histórico que analizamos se vincula a guardias, soldados, mozos o novatos en una institución, por lo que es posible entenderlos como conscriptos. En localidades como Tarapacá, Mamiña, Pica, Usmagama, Guaviña, Chiapa y Sibaya, entre otras, durante las fiestas patronales, en la noche de vísperas al día del santo, en el "parabién" (local), los alféreces bailan en parejas, aparte de la cueca y los huaynos, una danza denominada localmente como "cachimbo", acompañados musicalmente por comparsas de laquitas o bandas de bronce. Antiguamente se interpretaba con guitarra, acordeón, mandolina o violín.

81 José Portugal Catacora, Danzas y bailes del Altiplano, Lima, Editorial Universo, 1981, 75. Este autor precisa que en algunos ayllus puneños, aparte de la influencia militar, la Iglesia adventista introdujo aerófonos de metal.

82 Simeón Villca Ticona, Llica, Provincia Daniel Campos, La Paz, Nuevo Siglo, 2002, 176.

83 Urzúa, op . cit., 86.

84 Fuenzalida, op. cit., 46.

85 AHVD, Oficios emitidos, 1922, vol 335, oficio $\mathrm{N}^{\circ} 1165$. 
En los santuarios nortinos, como los consagrados a la Virgen del Rosario de Las Peñas ${ }^{86}$, a la Virgen del Carmen de La Tirana ${ }^{87}$, a la Virgen de los Remedios de Timalchaca ${ }^{88}$, al Señor de $\operatorname{Sipiza}^{89}$ y a San Lorenzo de Tarapacá ${ }^{90}$, donde asistía

86 Luis Urzúa describe el impacto que causaba la introducción de las bandas de bronce en la fiesta del Santuario de la Virgen de Las Peñas. Al respecto este sacerdote anotó: "Calcúlese lo que será el bullicio de los bronces, matracas, zampoñas y bombos en ese encajonamiento de muros de piedra, de más de mil metros de altura, unido a la detonación de cohetes, petardos y dinamita [...] Las personas acostumbradas al recogimiento silencioso del lugar sagrado, consideran una profanación el estruendo de los bronces en el templo, unido a la trama de pasos rítmicos. Califican ligeramente de residuos paganos estas audacias, olvidando las danzas de David frente al arca del testamento [...] Siempre se acompañan con el tambor y el bombo. A veces, también, con instrumentos de bronce. De esta manera se produce una sinfonía impresionante en los espacios en que termina el canto, vibran las matracas y la danza se mueve con tonos marciales". Urzúa, op. cit., 253-254. El destacado es nuestro.

87 En el santuario de La Tirana se dispuso que "en horas de la tarde, se iniciará la tradicional procesión de la imagen de la Virgen y se izará el pabellón nacional en el frontis de la iglesia. Una banda militar ejecutará los acordes del Himno Patrio". El Tarapacá, 15 de julio de 1952. En este mismo período, Juan Uribe Echeverría menciona brevemente las bandas de bronce, registrando algunas fotografías sobre los bailes religiosos y los músicos. Juan Uribe Echeverría, Fiesta de La Tirana de Tarapacá, Valparaíso, Ediciones Universitarias de Valparaíso, 1973.

88 En Timalchaca, "la plaza abunda de gente que se desentume a la espera de la fiesta. Hay tres bandas de instrumentos de bronce y una de zampoñas, llegadas de Ticnamar, Guatanabi, Tímar y Marquirabi. Las ceremonias empiezan con la formación de los carabineros, conscriptos, reservistas y bandas, al mando del sargento don Ángel Aracena, el Capellán, vestido de Oficial de Ejército, recibe la cuenta. Se iza la bandera, flamante y enternecedora, que los del lugar la guardan como una joya entre las vestiduras preciosas de la Virgen, se entona el Himno Nacional y se inicia el espectacular desfile, con sonoridades marciales, a cuyo término se escucha una alocución patriótica. Enseguida, todos pasan al templo donde hay misa cantada y numerosas comuniones". Urzúa, op. cit., 205.

89 El Santuario del Señor de Sipiza, ubicado en la quebrada de Aroma, celebra cada año al Espíritu Santo. Esta festividad tarapaqueña tuvo una gran significación regional durante el siglo XIX, siendo el sitio principal de peregrinación para los "novenantes" andinos. El templo es uno de los más grandes de la zona y ha sufrido derrumbes, producto de terremotos e incendios. Con los años, la fiesta fue perdiendo importancia regional debido a la lejanía del lugar, la inexistencia de caminos y el apogeo que tuvo la fiesta de La Tirana. Sin embargo, aún las poblaciones andinas participan de la fiesta con todo el sistema de cargos en plena función. En 1901, el párroco de Sibaya informó que: "En conformidad con los deseos de S.S. Ilma., hice en este pueblo la fiesta de Pentecostés y en la tarde del mismo día 16 fuí á Jaiña, donde estuve dos días, regresando ayer á este lugar de Sipisa. Muy distinto es mi duda, el espiritu que mima á los concurrentes á uno y otro lugar. Si bien es cierto que acá en Sipiza hay siempre bastante borrachera entre los indios del mismo lugar, no puede negarse que á la gente que acude de otros pueblos la lleva una verdadera devoción, un verdadero espíritu de piedad y religión". Archivo del Obispado de Iquique (en adelante AOI), "Párroco visita a Sipiza", Carpeta Sipiza (1901-1905).

90 En Tarapacá, para la festividad de San Lorenzo del 9 y 10 de agosto de 1931, se programaron las siguientes actividades:

"Día 9: A las 7 horas - La banda recorrerá las calles de la población tocando dianas

A las 12 horas - Gran retreta en la plaza del pueblo Eleuterio Ramírez.

A las 16 horas - Entradas de ceras por los fieles y concurrencia de los bailes religiosos.

A las 17 horas - Recepción en el local del "Para Bien", a todos los fieles y componentes de los bailes.

A las 21 horas - Grandes Vísperas en la Iglesia del pueblo.

A las 21:30 horas - Fuegos artificiales y elevación de globos.

A las 23 horas - Grandes bailes familiares.

Día 10: A las 7 horas - La banda recorrerá las calles de la población.

9 horas - Misa de Comunión, cantada por el Coro de Pica.

A las 11 horas - Misa solemne en homenaje del Santo Patrono, con asistencia de las autoridades, directiva de las festividades, bailes religiosos y feligreses en general.

A las 12 horas - Retreta en la plaza en que la banda tocará piezas de su variado programa.

A las 16 horas - Gran procesión en homenaje al Santo Patrono San Lorenzo, acompañado del Santísimo con la asistencia de los feligreses y bailes religiosos. 
una gran cantidad de peregrinos y bailes religiosos (morenos, chunchos, llameras, diabladas, indios pieles rojas, etc.), el sonido amplificado de la banda de bronce permitió que todos los bailarines, en las plazas o explanadas, siguieran al unísono el compás de las mudanzas de las cofradías ${ }^{91}$.

La consolidación de las bandas de bronce como expresión musical, hacia mediados del siglo XX, no solamente ha permitido que las poblaciones indígenas las integren a sus ceremonias o acompañen con estas sus bailes tradicionales, sino que también abrió un sistema de interacción entre indígenas y no indígenas, permitiendo visibilizar los ritos, las danzas y las melodías en una variedad de expresiones de la cultura y religiosidad popular del norte chileno.

\section{AlgunAS REFLEXIONES}

Como hemos constatado, los comuneros andinos, durante las primeras décadas del siglo XX, pasaron a engrosar las filas de las instituciones castrenses, ya sea como reclutas o como personal contratado una vez finalizado el servicio militar. En los regimientos, accedieron a trabajos como sastres, mecánicos, electricistas o músicos, participando del sistema logístico que la reforma prusiana establecía en todos los cuarteles del país. Al participar del sistema de enrolamiento, van asumiendo los compromisos con Chile, como sujetos políticos que se integran al quehacer ciudadano del Estado-Nación.

La reestructuración del Ejército posibilitó que, entre otras alternativas laborales, ingresaran como músicos de batallón, aprendiendo a interpretar instrumentos de bronce que las bandas instrumentales de los regimientos recientemente habían incorporado. Las bandas militares acompañaron, con marchas prusianas, desfiles oficiales, himnos marciales, retretas u orfeones en las plazas, quioscos o calles de las ciudades nortinas y los poblados cordilleranos. Bajo esta dinámica, paulatinamente los soldados-músicos-andinos adaptaron sus antiguas melodías al sonido amplificado de los instrumentos de metal. La respuesta comunitaria a este proceso fue reproducir la banda militar en la tradición cultural andina, principalmente en las fiestas patronales.

Así, a medida que avanzaba el siglo XX, las ceremonias religiosas se llenaron del timbre agudo de la trompeta o de los telúricos acordes de las tubas, organizán-

A las 18 horas - Atención a los Alféreces de las festividades y bailes religiosos y feligreses en general.

A las 21 horas - Fuegos artificiales

A las 22 horas - Retreta en la plaza Eleuterio Ramírez.

A las 23 horas - Baile familiar". El Tarapacá, 5 de agosto de 1931. El destacado es nuestro.

91 El folclorista chileno Oreste Plath, hacia 1950, realizó una serie de registros, además de recibir informaciones de profesores, sacerdotes y lugareños sobre festividades, donde describe las fiestas y los bailes religiosos en el norte chileno, además de la participación de las bandas de músicos para acompañar a las cofradías. Realizó cortas descripciones de pueblos como Mamiña, Pica, La Tirana, Ayquina y Las Peñas. Véase Oreste Plath, En viaje, Santiago, Empresa de Ferrocarriles del Estado, 1951 
dose diferentes agrupaciones o bandas de música en poblados precordilleranos o altiplánicos, para acompañar al alférez durante el tiempo sagrado de la festividad o a los bailes religiosos en los santuarios nortinos.

La ritualidad que se desplegaba en la fiesta fue resemantizada, incorporando creativamente instrumentos, marchas, cánticos militares, himnos y dianas a la estructura del rito, como "vías de apropiación y producción cultural” o maneras de "hacer" en la ritualidad"2. La incorporación de la banda de bronce en los Andes reactualiza la ritualidad, y no necesariamente fractura las costumbres tradicionales, las cuales responden ciertamente a construcciones sociales e invenciones de otras épocas que, del mismo modo, fueron introducidas en la performance del rito ${ }^{93}$ (como los carnavales, santos patronos, fiestas de las Cruces, instrumentos de cuerdas, etc.). Las bandas en las fiestas andinas manifiestan una lectura agencial, que los segmentos indígenas realizaron de la modernidad en la cual se integraron desde el siglo XIX ${ }^{94}$. Así, mediante la ritualidad, la comunidad incorpora dinámicamente elementos modernos, como formas prácticas que se integran en el tejido social de la vida comunitaria, mediante ritos de inversión ${ }^{95}$. Una visión esencialista, que apunte a una matriz cultural, fisura la capacidad de acción y cambio de los indígenas, de la cual históricamente hemos sido testigos.

92 Al respecto, véase Michel de Certeau, La invención de lo cotidiano, vol. I: Artes de hacer, México D.F., Universidad Iberoamericana, 1996; Guillaume Boccara, “Antropología Diacrónica. Dinámicas culturales, procesos históricos y poder político", en Guillaume Boccara y Sylvia Galindo (eds.), Lógica mestiza en América, Temuco, Ediciones Universidad de La Frontera-Instituto de Estudios Indígenas, 2000.

93 Sobre los aspectos simbólicos, Martínez infiere que con las bandas "se da también una nueva oposición en extremo significativa, que al comienzo nos sorprendió: empezamos nuestra indagación de terreno en Manqha saya (parcialidad de abajo), y aquí todos los serenos están destinados a instrumentos de Metal, las bandas de Bronces. Quedando para las 'cañas' -sikuras, lakas, lichiwayo- instrumentos autóctonos, como se sabe, el sereno del Pueblo de Isluga, Uma Palka, por esencia depositario de la tradición. De este modo, se nos forjó la idea de que en cada estancia había un solo sereno siempre. Sin embargo, al investigar en Arajj Saya (parcialidad de arriba), de inmediato aparecieron dos serenos: uno para banda de metal y otro para cañas. Dándose, entonces, en Arajj Saya la oposición metal/cañas con toda nitidez. Que podría tal vez ser entendida como oposición de lo nuevo/viejo, o moderno/tradicional". Gabriel Martínez, "El sistema de los Uywiris en Isluga", en idem, Espacio y Pensamiento, La Paz, Ediciones Hisbol, 1989, 55. Es necesario comentar que los serenos (sireno o sirenas como también suelen llamarlos) corresponden a la deidad de la música (deidad acuática que está presente en saltos de agua, riachuelos u ojos de agua o juturi), permitiendo afinar los instrumentos, instruir a versados músicos o inspirar melodías; aunque existe temor de que el encuentro con sireno podría generar locura en el músico o la desaparición de este. Si hay sireno para instrumentos tradicionales, también fue resemantizado un sireno para las bandas de bronces, interpretadas tanto en el altiplano como en las quebradas. La costumbre indica que antes de tocar en las festividades, se debe rogar al sireno para que acompañe a la banda o la tropa de lacas, en un rito denominado localmente como las veces. En el rito andino, se integran simbolismos y significantes que van a la tradición y a la incorporación de nuevos elementos, tal como advertía Martínez en la década de 1970 .

94 Piotr Sztompka, Sociología del cambio social, Madrid, Alianza, 1995.

95 James Scott, Los dominados y el arte de la resistencia. Discursos ocultos, México D.F., Ediciones Era, 2000. 
Hoy, es casi imposible entender una festividad o un ritual -eventos comunitarios, celebraciones religiosas, bailes religiosos en las ciudades, poblados andinos o santuarios como Timalcha, Sipiza, Ayquina, Las Peñas o La Tirana- si no participa la banda de bronce ${ }^{96}$.

En síntesis, los indígenas andinos, en el tablado del reclutamiento y la ciudadanía, incorporan dinámicamente a sus expresiones musicales las bandas, actualizando sus costumbres y reorientando el contenido semántico de los ritos, la música y la cultura en los Andes.

96 Las bandas más reconocidas en los últimos años en el norte de Chile son, en Iquique, Los Wiracoha, Juventud de Norte, Reales, Ases, Juventud del Norte, Los Mallkus, Runaukas, Los Humildes, Santa Cecilia de Mamiña, Sensación Andina, Hijos del viento, Nazarenos y los Yatiris, entre otros; en Arica, Los Tigres, La Santa Cecilia y Juventud del Folclore; en Antofagasta, Los Rebeldes, Los Totes, Nueva Ilusión, Real Amaru, Los Primos, Los Ulises y La Autentica; en Calama, Santa Cecilia, Carismática, Super Premier y Continental; en Tocopilla, Los Ecos y Los Santis y Nueva juventud; además de numerosas bandas de pueblos y de nuevas agrupaciones que surgen en los colegios del norte de Chile. En la actualidad las bandas de bronce cuentan con instrumentos de percusión (bombo, caja y platillos, aunque durante las últimas décadas se ha incorporado una timbaleta para animar las fiestas patronales, sobre todo los ritmos de cumbia). Se mantienen las trompetas, los bajos o trombones y las tubas. Suelen tener un director, el cual es el "arreglador" del grupo o el que "saca" los temas, debido a que posee mayor facilidad para interpretar y un notable dominio de las variables tonales de los aerófonos, así como la pericia para aprender las nuevas melodías. En muchos casos es el que compone los temas o realiza los arreglos musicales y es el que "lee" partituras, traspasando la información musical al resto de la banda. El director de la banda, desde los primeros años de formación de esta corriente musical, viene a reemplazar al antiguo cacique o caporal de las comparsas de laquitas o lichiwayus, sustituyendo la noción tradicional propia de la pampa salitrera, como fue la figura del "maestro", personaje principal para la comarca y que ejercía influencia en la comunidad para organizar las festividades. Últimamente, las bandas tocan en eventos sociales urbanos, como carnavales, festivales, ferias artesanales, bailables y actividades de diferente índole. También asisten a algunos pueblos para la temporada de carnavales, acompañan a los difuntos en noviembre o ritos de corte de pelo, bautizos y matrimonios, entre otras actividades. Cuando hay fiestas de santuario, como La Tirana, Las Peñas o Ayquina, algunas cofradías contratan a bandas bolivianas (bandas como Central Cocani de Oruro, Pagador, Imperial, etc.) o peruanas, ya que cobran más barato que las chilenas. Los ritmos introducidos desde Bolivia que interpretan las bandas, aparte de los saltos de diabladas de mediados del siglo XX, son clasificados como bandas de danza pesada (ritmos de morenada) y danza liviana (llamerada, kullawada, tinku, pujllay, taquirari, caporales, antawara y otros). En Bolivia, incluso las bandas están compuestas por más de 100 integrantes. 


\section{ANEXO FOTOGRÁFICO}

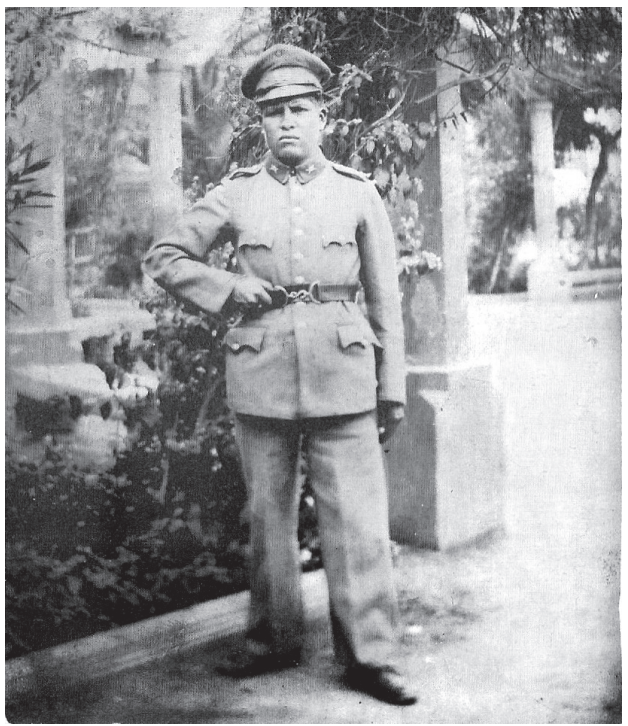

Francisco Vernal Nina, pueblo de Guaviña (1930 aprox..) ${ }^{97}$

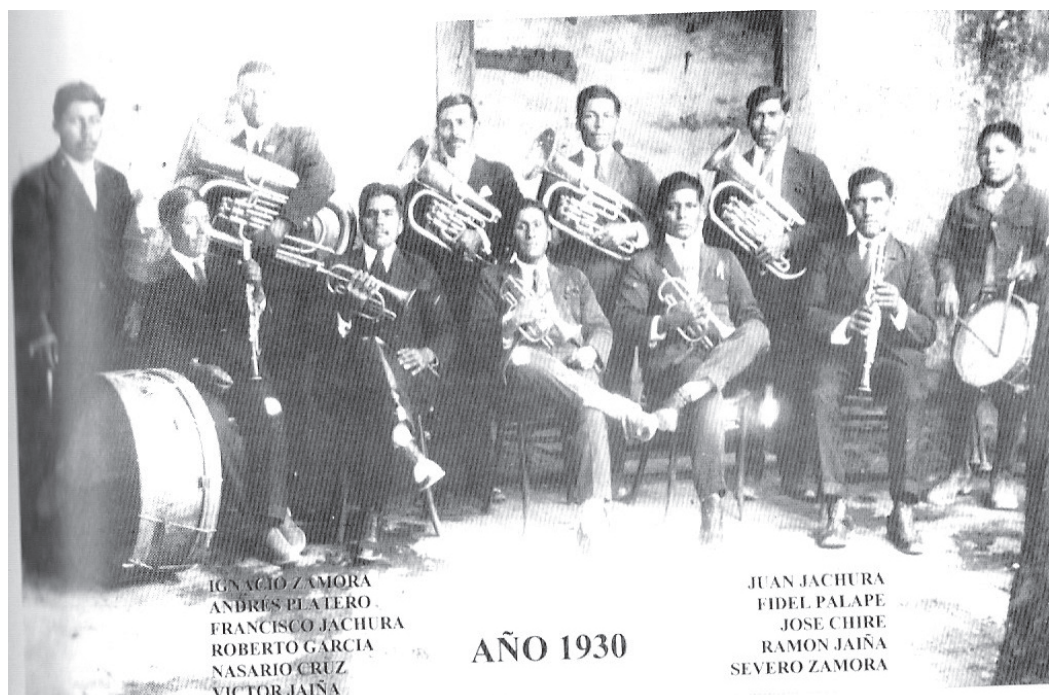

Banda de músicos militares de Guaviña, $1930^{98}$

97 Salazar Pincheira, Registro histórico fotográfico de la provincia de Iquique, op. cit.

98 Salazar Pincheira, Primer registro histórico-fotográfico de los Aymaras de la provincia de Iquique, op cit. 


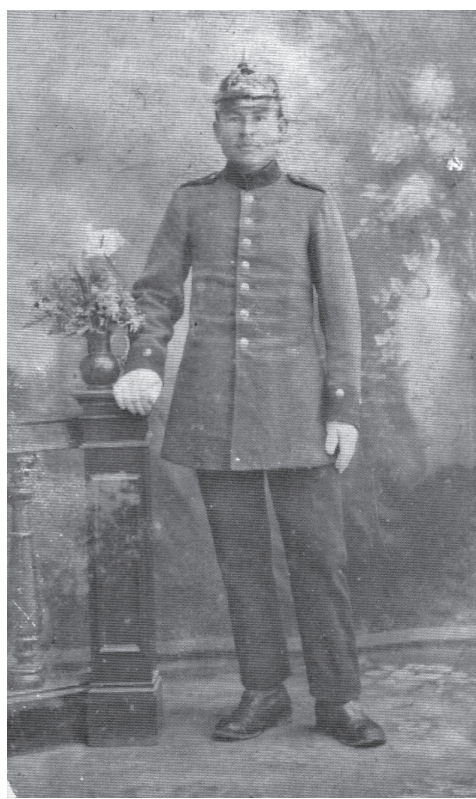

Tomás Zambrano Rivera, pueblo de Camiña (1910 aprox.) $)^{99}$

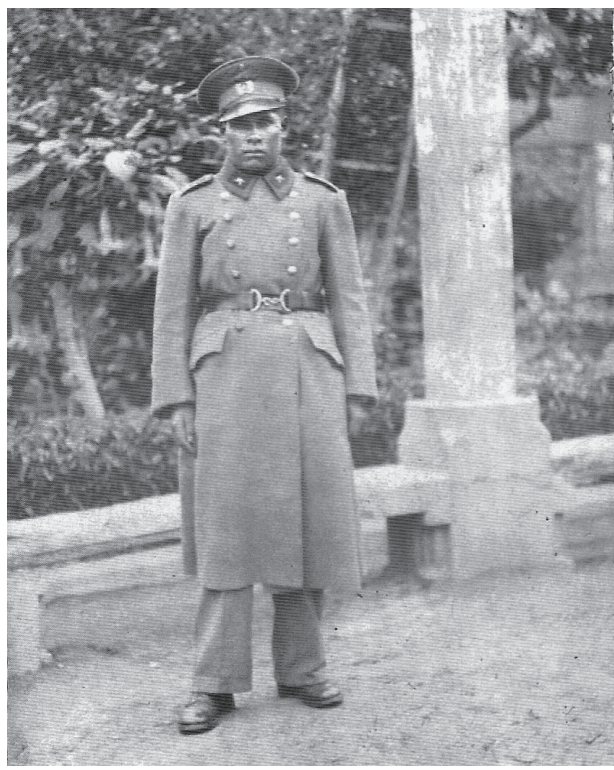

Lucas Hualampa Hualampa, pueblo de Sibaya ${ }^{100}$ 


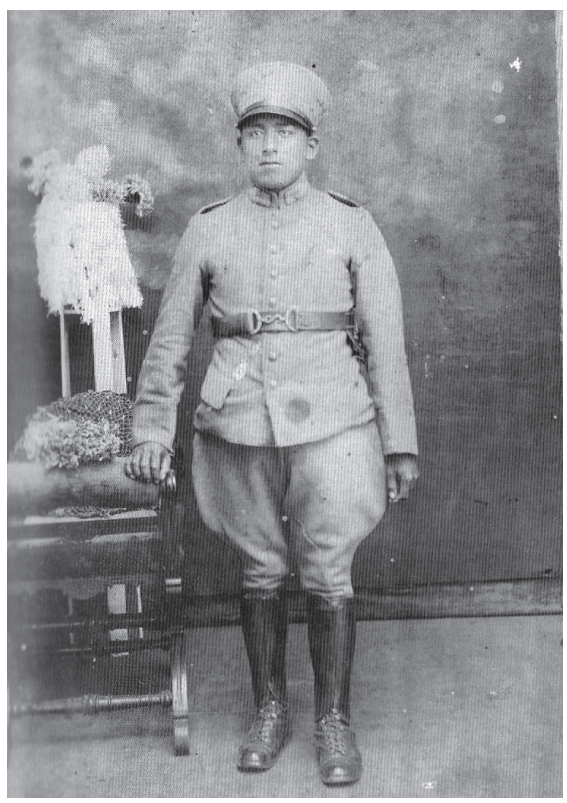

Eleodoro Salazar Guacte, pueblo de Laonzana. (1920 aprox.) $)^{101}$

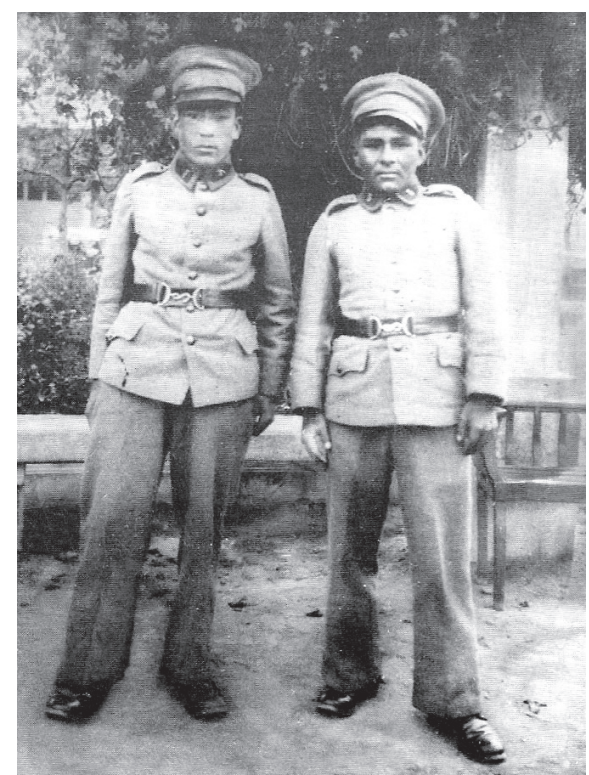

Jóvenes conscriptos provenientes del pueblo de Iquiuca (1920 aprox.) $)^{102}$

101 Idem.

102 Salazar Pincheira, Registro histórico-fotográfico de la provincia de Iquique, op. cit. 


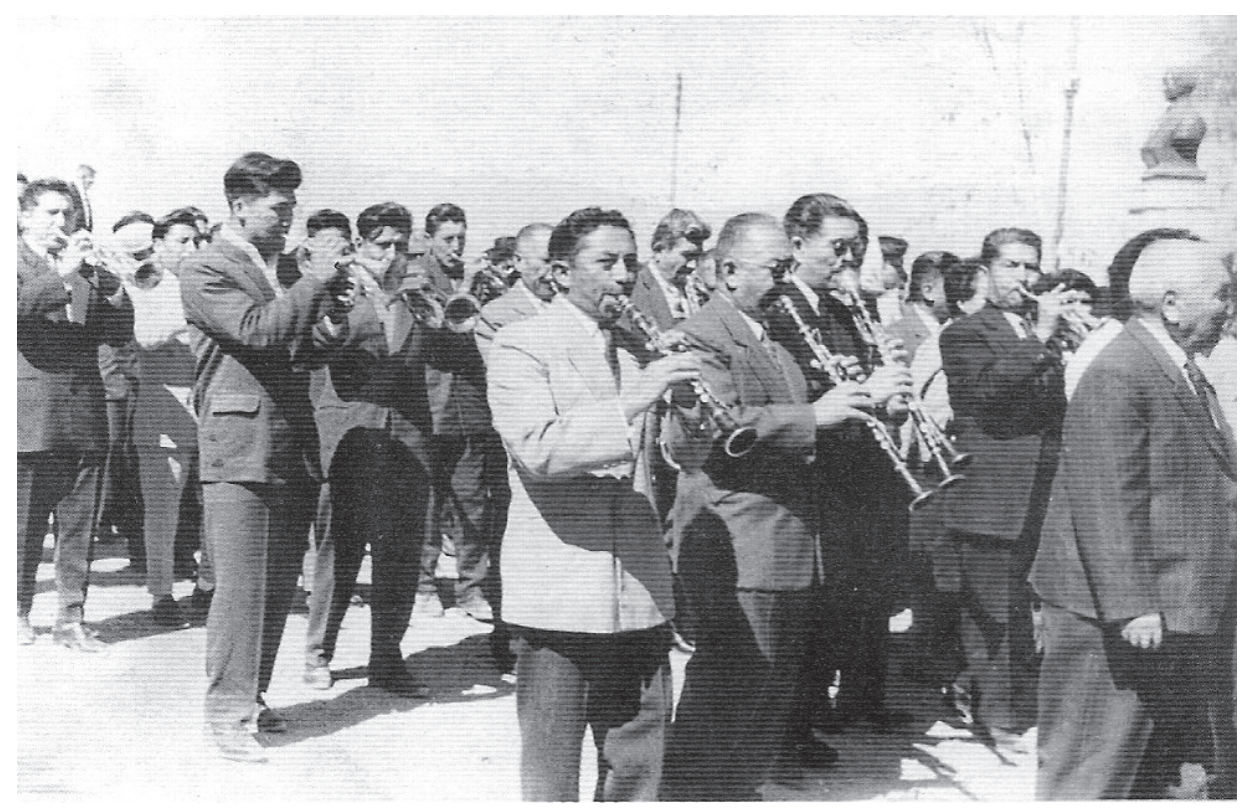

Banda de músicos andinos ex militares, década de $1950^{103}$

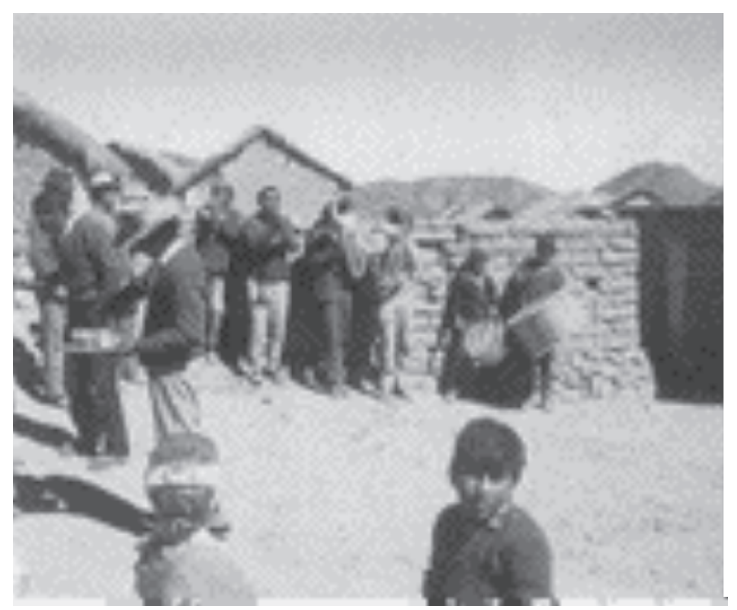

Banda de bronce en la Pachama, interior de Arica (década 1970 aprox.) ${ }^{104}$

103 Salazar Pincheira, Primer registro histórico-fotográfico de los Aymaras de la provincia de Iquique, op. cit.

104 Manuel Dannemann, Enciclopedia del folclore de Chile, Santiago, Editorial Universitaria, 1998. 


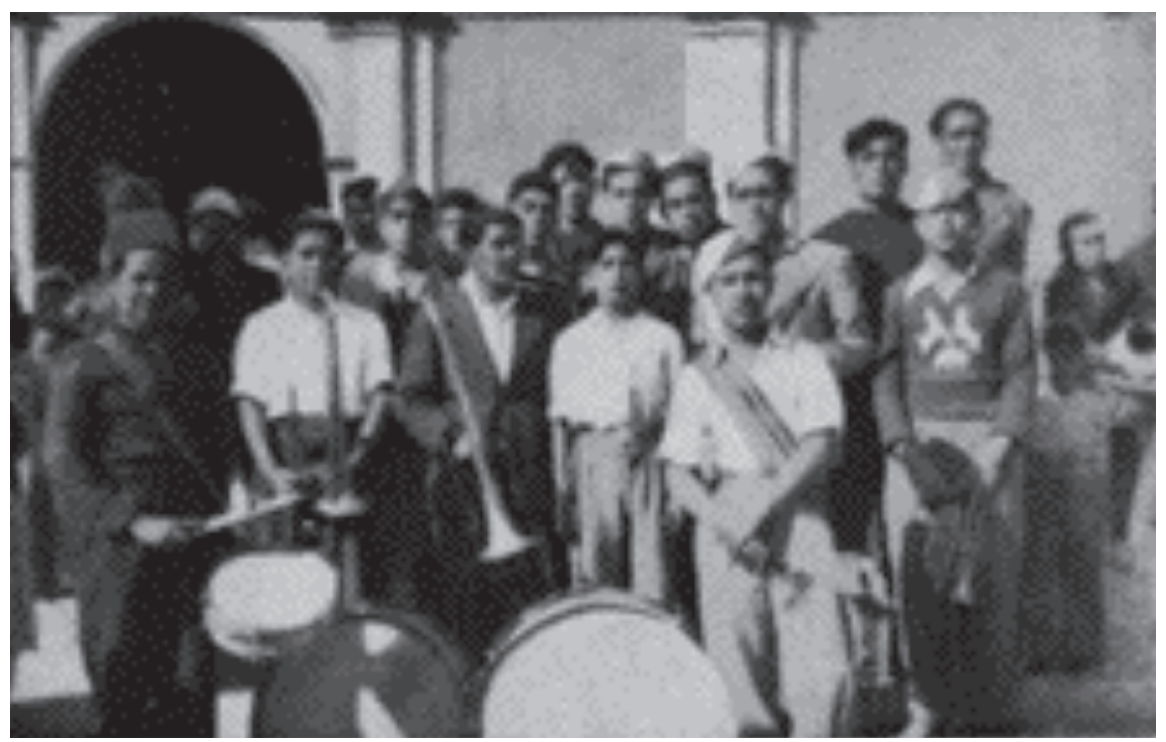

Banda de bronce con músicos andinos en La Tirana (1947) ${ }^{105}$

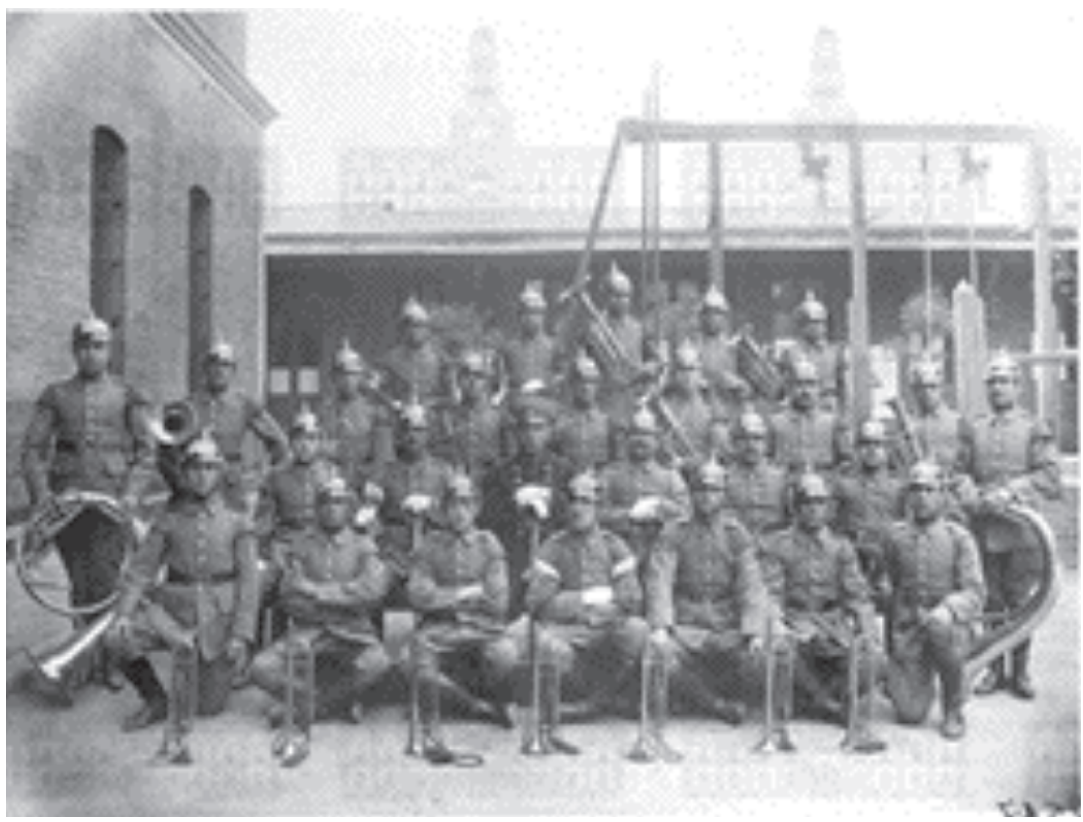

Banda de músicos del regimiento Cazadores $\mathrm{N}^{\circ} 2$, (comienzos del siglo XX aprox.) ${ }^{106}$

105 Uribe, op cit.

106 Salazar Pincheira, Registro histórico-fotográfico de la provincia de Iquique, op . cit. 


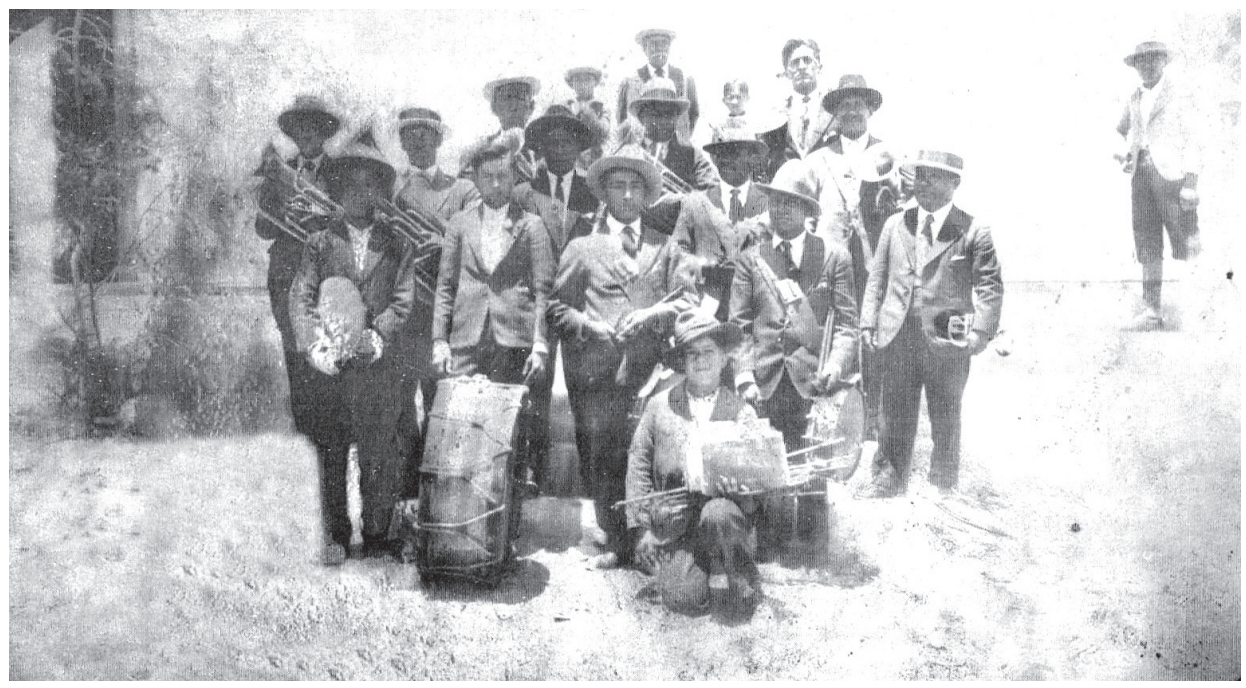

Banda de músicos andinos de Pica, década de $19400^{107}$

107 Salazar Pincheira, Registro histórico-fotográfico de la provincia de Iquique, op. cit. 
